\title{
MFC Communications Infrastructure Study
}

January 2012

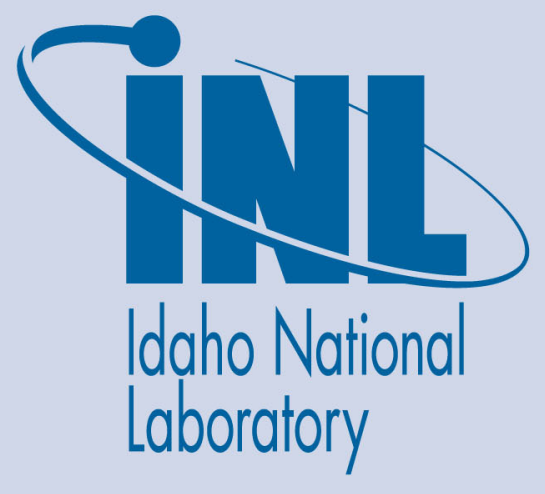

The INL is a U.S. Department of Energy National Laboratory operated by Battelle Energy Alliance 



\section{DISCLAIMER}

This information was prepared as an account of work sponsored by an agency of the U.S. Government. Neither the U.S. Government nor any agency thereof, nor any of their employees, makes any warranty, expressed or implied, or assumes any legal liability or responsibility for the accuracy, completeness, or usefulness, of any information, apparatus, product, or process disclosed, or represents that its use would not infringe privately owned rights. References herein to any specific commercial product, process, or service by trade name, trade mark, manufacturer, or otherwise, does not necessarily constitute or imply its endorsement, recommendation, or favoring by the U.S. Government or any agency thereof. The views and opinions of authors expressed herein do not necessarily state or reflect those of the U.S. Government or any agency thereof. 



\title{
MFC Communications Infrastructure Study
}

January 2012

\author{
Idaho National Laboratory \\ Infrastructure \\ Idaho Falls, Idaho 83415
}

http://www.inl.gov

Prepared for the

U.S. Department of Energy

Under DOE Idaho Operations Office

Contract DE-AC07-05ID14517 



\title{
Infrastructure
}

\section{MFC Communications Infrastructure Study}

\author{
INL/EXT-11-23733
}

January 2012

Approved by:

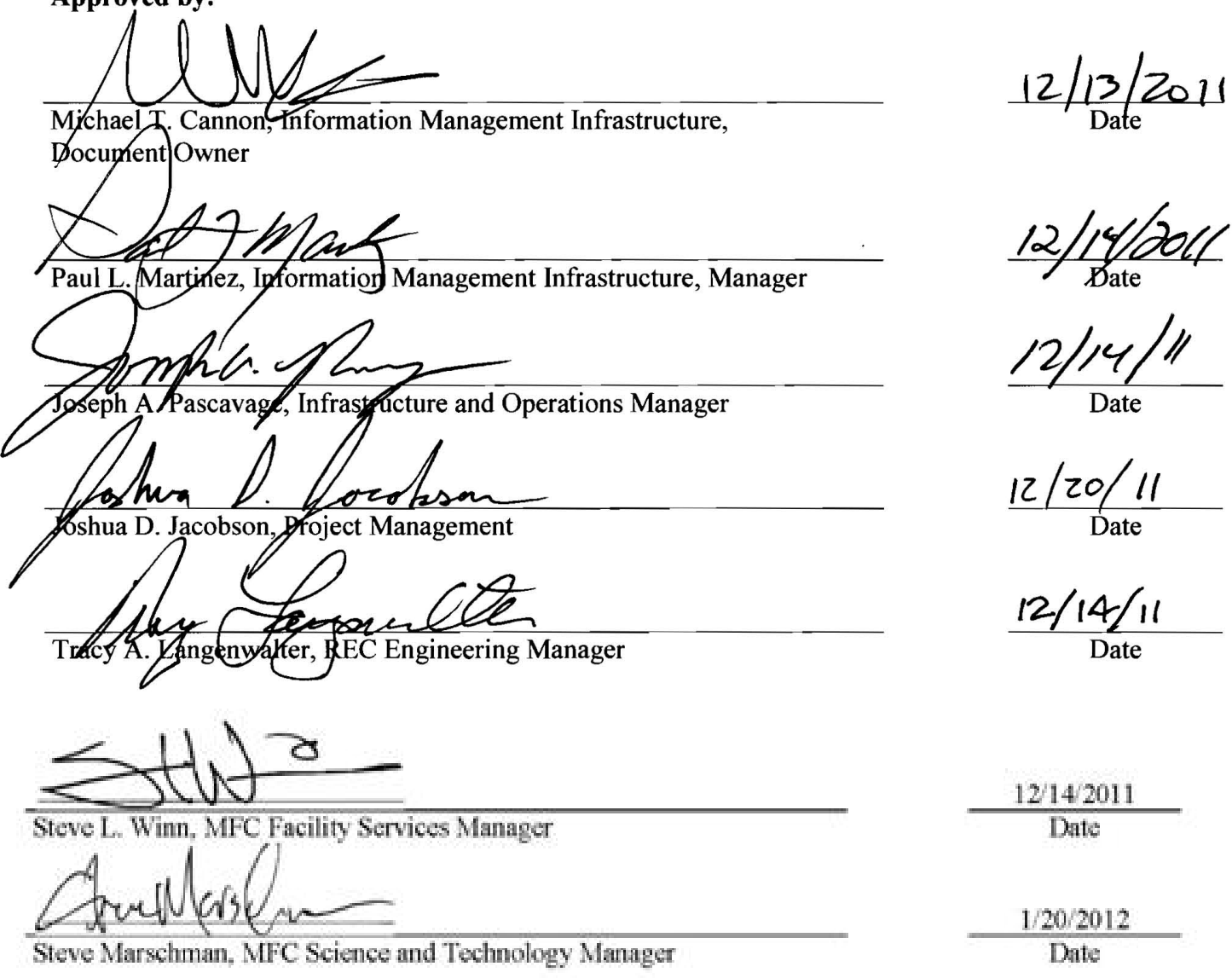


INTENTIONALLY BLANK 


\section{CONTENTS}

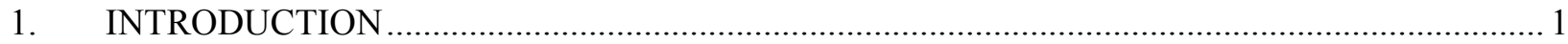

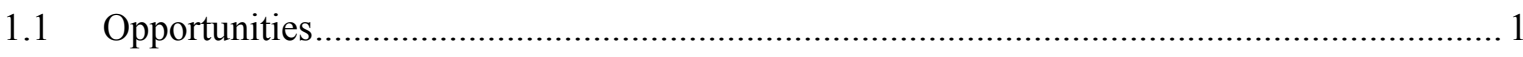

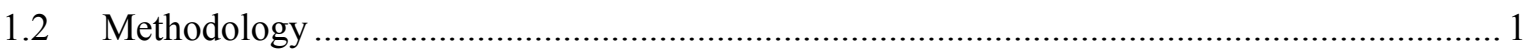

1.2.1 Assessment Steps (Figure 1. Study Approach) …..................................................... 2

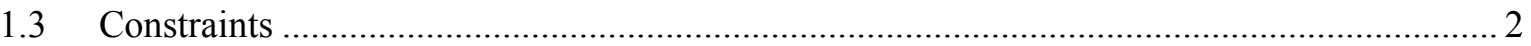

1.4 Assessment Information Sources …….................................................................. 2

2. ASSESSMENT SUMMARY OF MFC COMMUNICATIONS INFRASTRUCTURE

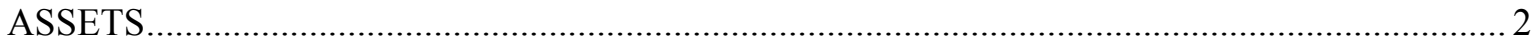

2.1 Communications Infrastructure Assessment Categories (STD-170) ..................................... 3

2.2 Communications Infrastructure Summary Data Presentation ............................................... 5

2.3 MFC Building Data Port Availability Bar Graph .......................................................... 9

2.4 Current MFC Multimedia/Video Conference Room Capability Summary .......................... 11

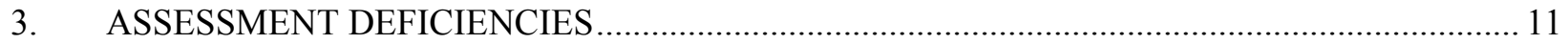

4. PROPOSED RECOMMENDATIONS IN PRIORITY ORDER ….......................................... 12

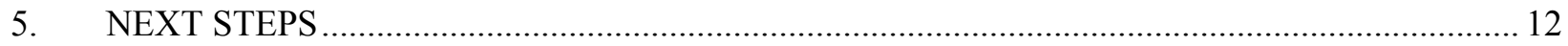

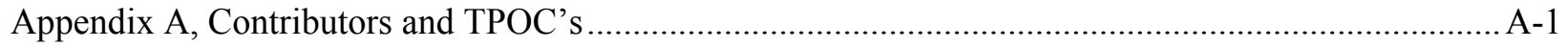

Appendix B, MFC Communications Study by Building Summary ................................................... B-1

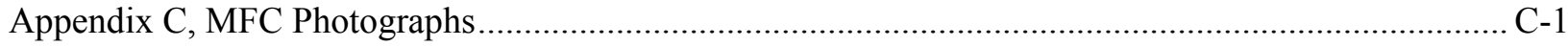

Appendix D, MFC Communications Infrastructure Drawings ........................................................ D-1

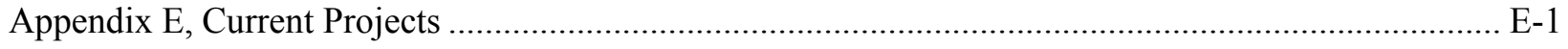

\section{FIGURES}

FIGURE 1. Study approach. 2

FIGURE 2. STD-170 Fiber Optic Cabling. Subsidiary buildings shall be supported by 48 single-mode fiber strands and core buildings shall be supported with 144 single-mode fiber strands.

FIgURE 3. STD-170 identifies Cat $6 \mathrm{~A}$ as standard (some buildings have a mix of cable types).

(Cat 3 is most deficient, whereas Cat 6a not deficient.).... 6

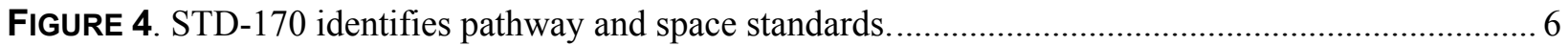

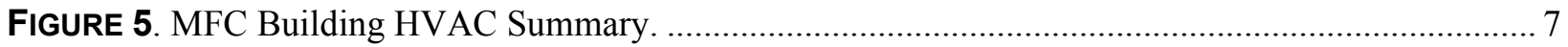


FIGURE 6. STD-170 identifies pathway and space standards......................................................... 7

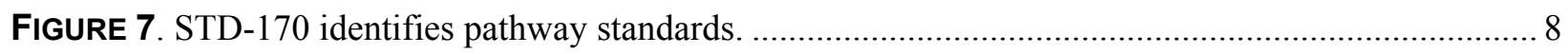

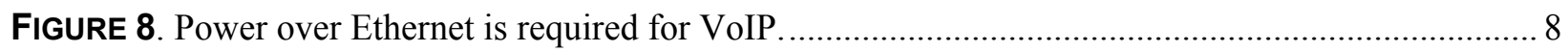




\section{ACRONYMS}

30YSP 30-Year Site Plan

AC Alternating Current

BEA Battelle Energy Alliance

Cat Category

CESB Contaminated Equipment Storage Building

CFA Central Facilities Area

CWI CH2M-WG Idaho, LLC

DOE Department of Energy

EDMS Electronic Document Management System

HVAC Heating, ventilation, and air conditioning

IAB INL Administration Building

iGPP Institutional General Plant Project

IM Information Management

IMCL Irradiated Materials Characterization Laboratory

INET Idaho National Engineering and Environmental Laboratory Computer Network

INL Idaho National Laboratory

IPL Integrated Priority List

L\&O Laboratory and Office

MFC Materials and Fuels Complex

MH Manhole/maintenance hole

MM Multimode

OSP Outside Plant

Pathways A cable route, either in duct back or conduit

PDS Premises Distribution Systems

PMO Project Management Office

PoE Power over Ethernet

TPOC Technical Point of Contact

TSB Technical Support Building

TYSP Ten Year Site Plan

UPS Uninterruptible Power Supply

VoIP Voice over Internet Protocol

VPN Virtual Private Network

VTC Video Teleconferencing Center

WFO Work for Others 


\section{DEFINITIONS}

Communication Infrastructure. (Telephony, network cabling, fiber, conference room video, dial rooms, alarms, conduits, routers, switches, communication closets/cabinets, power supplies and ventilation systems, manholes [MHs], hand holes).

Outside Plant (OSP). Physical cabling and supporting infrastructure (such as conduit, cabinets and any associated hardware located between a demarcation point in a dial room and a demarcation point in a building's telecommunication room.

Power over Ethernet (PoE). A solution where electrical current is run to networking hardware over the Ethernet Category five or higher data cabling. No extra alternating current (AC) power cord is needed at the product location, minimizing the amount of cable needed and/or the inconvenience of installing extra outlets.

Standard 170 ("Information Management Infrastructure Standards") (STD-170). A company document establishing information management (IM) infrastructure services to enable world-class facilities and the communications infrastructure requirements to support those services. These requirements build a sustainable and supportable model enabling the Idaho National Laboratory (INL) mission now and in the future.

Ten Year Site Plan (TYSP). Facilities planning document for a 10-year planning horizon. 


\section{MFC COMMUNICATIONS \\ INFRASTRUCTURE STUDY}

\section{INTRODUCTION}

Unprecedented growth of required telecommunications services and applications has changed the way the INL does business today. High speed connectivity combined with a high demand for telephony and network services requires a robust communications infrastructure to support the INL mission.

The current state of the Materials and Fuels Complex (MFC) communication infrastructure limits growth opportunities of current and future communications services and flexibility. This limitation is largely due to equipment capacity issues, aging cabling infrastructure (external/internal fiber and copper cable) and inadequate space for telecommunication equipment. While some communication infrastructure improvements have been implemented over time, projects have been completed without a clear overall plan and current technology standard.

This study identifies major and critical deficiencies with the current state of the communication infrastructure in operation at the MFC facilities and provides an analysis to identify needs and deficiencies to be addressed in order to achieve targeted architectural standards as defined in STD-170, "Information Management Infrastructure Standards." The intent of STD-170 is to provide a robust, flexible, long-term solution to make communications capabilities align with the INL mission and fit the various programmatic growth and expansion needs.

\subsection{Opportunities}

The communication infrastructure in operation at the MFC campus is aged with various types of technologies that no longer meet current communication infrastructure standards. This study evaluates the current state against the target architectural standards and provides input to an overall approach to facilitate the rehabilitation and future growth at MFC.

The objectives of this study are to:

1. Provide an integrated planning approach to identify the deficiencies in the as-is communications infrastructure as compared to STD-170.

2. Document the current communications infrastructure inventory and technologies at the MFC campus.

3. Provide a methodology to prioritize the major issues and concerns and provide input for strategic planning and funding determination.

\subsection{Methodology}

Communications infrastructure personnel physically inspected and created a current state communications infrastructure inventory of MFC using an assessment template for data consistency. The inventory is depicted in a series of business graphs (pie and bar charts) to provide a deeper understanding of the scope of the MFC network communication situation. Communication infrastructure personnel also created an overall campus communication infrastructure drawing as part of the inventory. Deficiencies have been identified in a broad context that will be used as input to future designs and projects.

A cost estimate must be performed for each identified project or for the entire MFC campus. 


\subsubsection{Assessment Steps (Figure 1. Study Approach)}

The basic steps of the study are as follows:

1. Perform physical assessment inventory for MFC campus.

2. Compare MFC communication inventory against INL approved STD-170.

3. Identify deficiencies between MFC inventory and STD-170.

4. Create an integrated MFC campus drawing.

5. Identify additional deficiencies from drawing as compared to STD-170.

6. Assess multimedia/video conferencing capabilities.

7. Publish study summary.

8. Provide prioritized list of recommendations (see next steps).

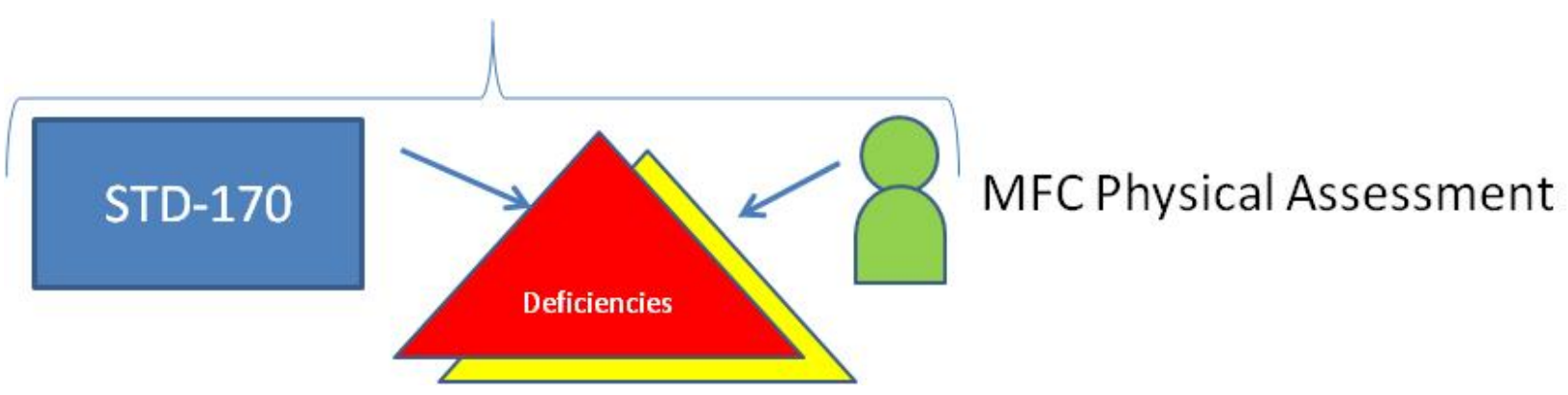

FIGURE 1. Study approach.

\subsection{Constraints}

- Funding to eliminate all identified deficiencies and standard alignment issues

- Senior management support and champion

- Budget reductions \& priorities.

\subsection{Assessment Information Sources}

- Physical assessment of over 90 structures/buildings by Y410 personnel

- 10-Year Site plan and MFC Campus Development plan

- STD-170, "Information Management Infrastructure Standards"

- Electronic Document Management System (EDMS) controlled drawings by building

- $\quad$ MFC Campus Drawing No. 438192

- Current Project Management Office (PMO) construction projects.

\section{ASSESSMENT SUMMARY OF MFC COMMUNICATIONS INFRASTRUCTURE ASSETS}

- 93 telecommunications rooms assessed

- 21 buildings are without fiber capacity and 36 are limited with multimode (MM) fiber 
- 54 buildings have non-standard cabling

- 17 buildings have insufficient uninterruptible power supply (UPS)

- 37 buildings have insufficient heating, ventilation, and air conditioning (HVAC)

- 41 buildings have insufficient space

- 30 building have insufficient conduit capacity

- 28 manholes

- 68 pathways

- 73 data switches.

\subsection{Communications Infrastructure Assessment Categories (STD-170)}

STD-170 was created to provide a telecommunication standard that has been adopted by stakeholders across the INL. A standard provides a target architecture that guides projects and maintenance tasks. STD-170 was used as the framework of comparative analysis for the MFC communications study. The MFC communication inventory was collected by inspection and compared against STD-170. The results are documented herein, with opportunities identified for improvements towards implementing STD-170.

The goal of STD-170 is to provide all INL workers with high-speed, reliable connectivity allowing access to internal and external applications. Future connectivity is ensured by adhering to standards as defined in STD-170.

The following categories represent the architecture and best practices that will lead the laboratory into the future while providing the most flexibility and capability to each end user in accomplishing the laboratory mission. All new building construction and maintenance will be specified to utilize the core service standards incorporated in the following categories. Each assessment area was analyzed using STD-170 as its basis.

The summary of the assessment is depicted in the tables and pictures in Appendixes B and C.

Table 1. STD-170 assessment categories (derived from Appendix A).

\section{STD-170 Assessment Categories (Derived from Appendix A)}

\begin{tabular}{|l|l|}
\hline $\begin{array}{l}\text { Fiber Infrastructure } \\
\text { Plant }\end{array}$ & $\begin{array}{l}\text { Subsidiary buildings shall be supported by } 48 \text { single-mode fiber strands and } \\
\text { core buildings shall be supported with } 144 \text { single-mode fiber strands. } \\
\text { Copper entrance facilities sized according to working space and number of } \\
\text { tenants. }\end{array}$ \\
\hline Copper Inside Cabling & $\begin{array}{l}\text { The building shall be cabled with a certified 10-gigabit capable Ethernet } \\
\text { copper cable using at a minimum category (Cat) 6A cabling system. }\end{array}$ \\
\hline Voice/Data Services & $\begin{array}{l}\text { Voice services provide highly reliable analogue, digital or voice over } \\
\text { Internet protocol (VolP) services to the desktop. Voice services support fax, } \\
\text { fire alarm, and special circuits that meet INL communication needs. Voice } \\
\text { mail, audio conferencing, and enhanced features are available. }\end{array}$ \\
\hline Electrical Power/UPS & $\begin{array}{l}\text { Each telecommunications room shall have two dedicated electrical panels. } \\
\text { Each panel shall have a minimum of a } 100 \text { amp service, for a minimum } \\
\text { total of } 200 \text { amp service per telecommunications room, unless dictated } \\
\text { otherwise by IM Infrastructure. If there is a building UPS available, one } \\
\text { panel shall provide power from the UPS system. } \\
\text { Telecommunications rooms shall be backed up by emergency generator } \\
\text { power and shall be on a building UPS system. }\end{array}$ \\
\hline
\end{tabular}




\begin{tabular}{|l|l|}
\hline \multicolumn{2}{|l|}{ STD-170 Assessment Categories (Derived from Appendix A) } \\
\hline Environmental \\
Controls (HVAC) & $\begin{array}{l}\text { Dial rooms shall maintain continuous and dedicated HVAC } 24 \text { hours a day, } \\
365 \text { days per year. Dial rooms shall have an ambient temperature range } \\
\text { between } 64^{\circ} \mathrm{F} \text { and } 75^{\circ} \mathrm{F} \text { with a desired variance of no more than } \pm 5^{\circ} \mathrm{F} \text { in } \\
\text { ambient temperature. Humidity range shall be maintained between } 30 \% \text { to } \\
55 \%, \text { non-condensing. Dial rooms shall maintain positive pressure with a } \\
\text { minimum of one air change per hour. }\end{array}$ \\
\hline Space & $\begin{array}{l}\text { Physical dedicated room for communications infrastructure. Space shall } \\
\text { have secured access. Space requirements are driven by cabling, power, } \\
\text { and other factors. }\end{array}$ \\
\hline Multimedia \& Video & $\begin{array}{l}\text { All conference rooms shall have multimedia capabilities, which include a } \\
\text { projection screen, audio, microphones, and adequate lighting control. } \\
\text { Conference rooms shall also include a specialized phone with full-duplex } \\
\text { noise cancelling technology. } \\
\text { Unclassified video conferencing allows for real-time interaction, which } \\
\text { supports content sharing and collaboration. Video conferencing is optional } \\
\text { and can be installed in requested rooms, areas, or facilities. }\end{array}$ \\
\hline Conduits & $\begin{array}{l}\text { A minimum of four, 4-inch conduits shall be installed for the } \\
\text { telecommunications systems entering the building. }\end{array}$ \\
\hline $\begin{array}{l}\text { Manholes/Maintenance } \\
\text { Holes }\end{array}$ & $\begin{array}{l}\text { Maintenance holes shall have a minimum of } 96 \text { square feet of floor area, } \\
\text { with a minimum height of } 8 \text { feet. } \\
\text { Maintenance holes are to be reinforced concrete, either poured in place or } \\
\text { pre-cast, and must be rated for } 20 \text {-ton (HS20-44 AASHTO) highway load } \\
\text { where designated. }\end{array}$ \\
\hline PoE & $\begin{array}{l}\text { Minimum size of cable tray shall be 12 inches wide and } 4 \text { inches deep and } \\
\text { not to exceed } 40 \% \text { maximum fill rate. Cable tray shall have a minimum of } \\
12 \text { inches of space above the cable tray and a minimum of } 3 \text { inches } \\
\text { separation below the cable tray. }\end{array}$ \\
\hline $\begin{array}{l}\text { PoE technology describes a system to pass electrical power safely, along } \\
\text { with data, on Ethernet cabling for VOIP, Wireless Access Points, and } \\
\text { Ethernet cameras. }\end{array}$ \\
\hline
\end{tabular}

Other optional infrastructure components were evaluated and included based on STD-170 to provide a holistic approach in providing communication services.

Additional Assessment Categories from STD-170 may be utilized in the future for enhanced planning and improved service delivery.

Other communication infrastructure services are optionally available at either core or subsidiary buildings. New construction and maintenance are driven by mission and programmatic requirements and needs. Based on those needs, additional communications infrastructure services may be required. STD-170 ensures the base infrastructure is in place to build upon for these services. The following categories are defined as optional; however, these services may be required. As these services are utilized and matured, the demand for communications infrastructure will increase the footprint needed to be maintained. 
Table 2. STD-170 optional assessment categories.

\begin{tabular}{|l|l|}
\hline STD-170 Optional Assessment Categories \\
\hline Encrypted Networks & $\begin{array}{l}\text { Encrypted networking is provided for INL resources, both internal } \\
\text { and external. Virtual Private Networks (VPNs) allow workers to } \\
\text { securely connect across public or private networks. INL also } \\
\text { provides networks suitable for use with federally classified material. }\end{array}$ \\
\hline Special Services Transport & $\begin{array}{l}\text { This service provides connectivity for customers for application } \\
\text { specific requirements. Examples of these services are telemetry, } \\
\text { remote monitoring, security, life safety, land mobile radio, card } \\
\text { readers and alarms. }\end{array}$ \\
\hline Wireless Network & $\begin{array}{l}\text { A wireless network shall be provided with short-range, high-speed, } \\
\text { data wireless services unless prohibited by security. The wireless } \\
\text { network shall be secured by advanced encryption and authentication } \\
\text { techniques. }\end{array}$ \\
\hline $\begin{array}{l}\text { Multimedia/Video } \\
\text { Teleconferencing Center } \\
\text { (VTC) }\end{array}$ & $\begin{array}{l}\text { This service provides seamless presentation capability from a } \\
\text { variety of sources. The multimedia capabilities allow personnel to } \\
\text { share information effectively utilizing standards based displays and } \\
\text { control systems. As needed video conferencing is a service added to } \\
\text { these rooms. }\end{array}$ \\
\hline
\end{tabular}

\subsection{Communications Infrastructure Summary Data Presentation}

A physical assessment of 93 telecommunication rooms was used to determine the current state of the communication infrastructure. A detailed assessment form was created for each building inspected. The detailed assessment forms were used to create a summary view of the data collected. The data is summarized and depicted in pie and bar graphs. The summary tables and pictures and are shown in Appendixes B and C. The detailed assessment forms are available upon request from the assessment lead and are located on the Y410 shared drive. It is important to note some buildings have multiple communications rooms.

\section{MFC Building Fiber Summary}

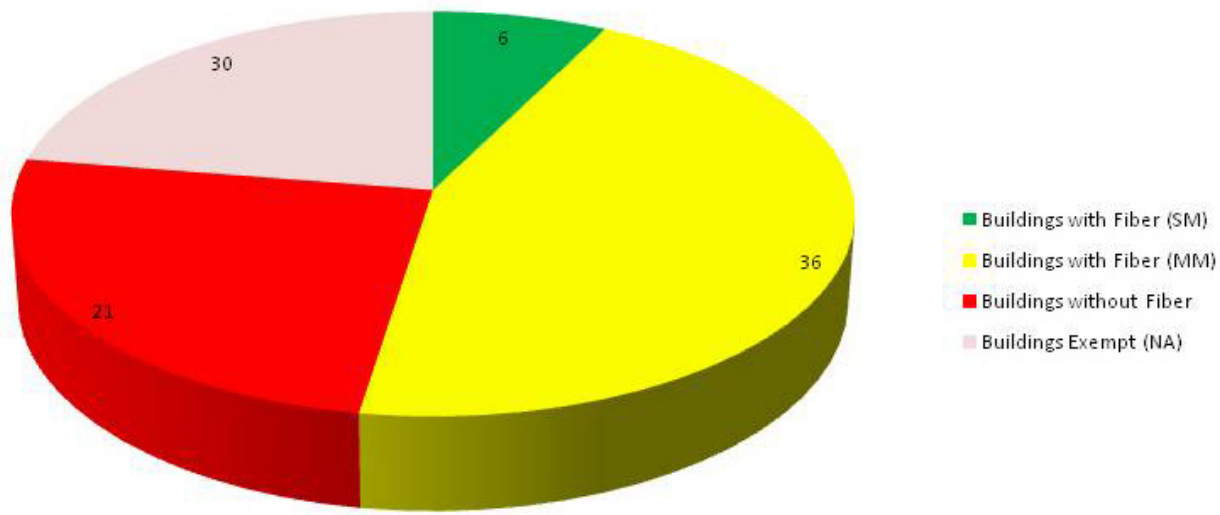

FIGURE 2. STD-170 Fiber Optic Cabling. Subsidiary buildings shall be supported by 48 single-mode fiber strands and core buildings shall be supported with 144 single-mode fiber strands. 


\section{MFC Building Cabling Deficiency Summary}

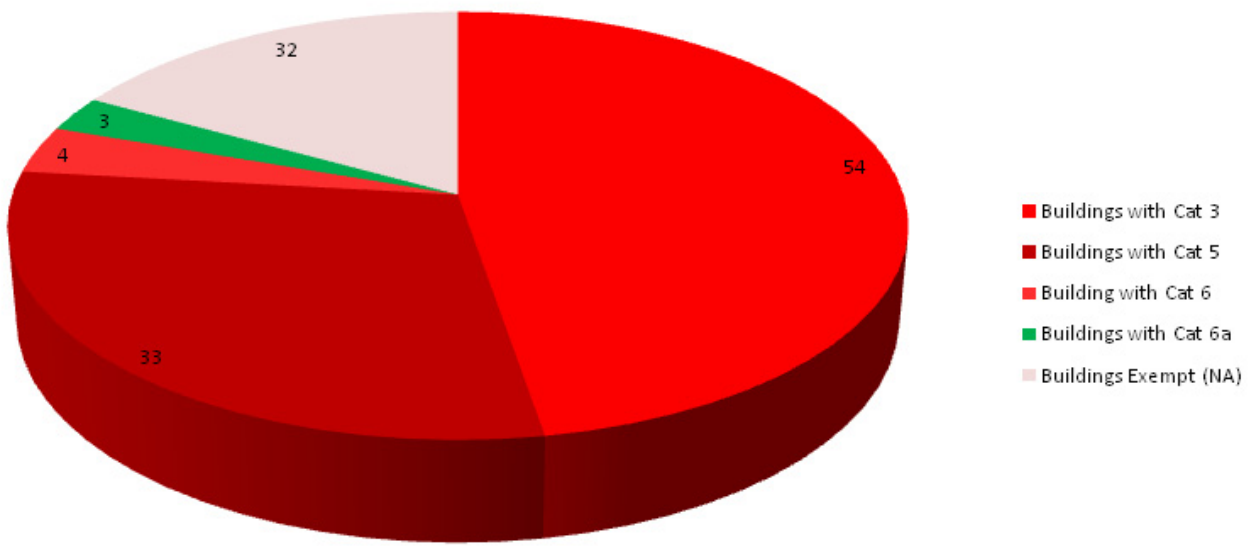

STD-170 identifies CAT 6A as standard (some buildings have a mix of cable types).

FIGURE 3. STD-170 identifies Cat 6A as standard (some buildings have a mix of cable types). (Cat 3 is most deficient, whereas Cat 6a not deficient.)

\section{MFC Building UPS Summary}

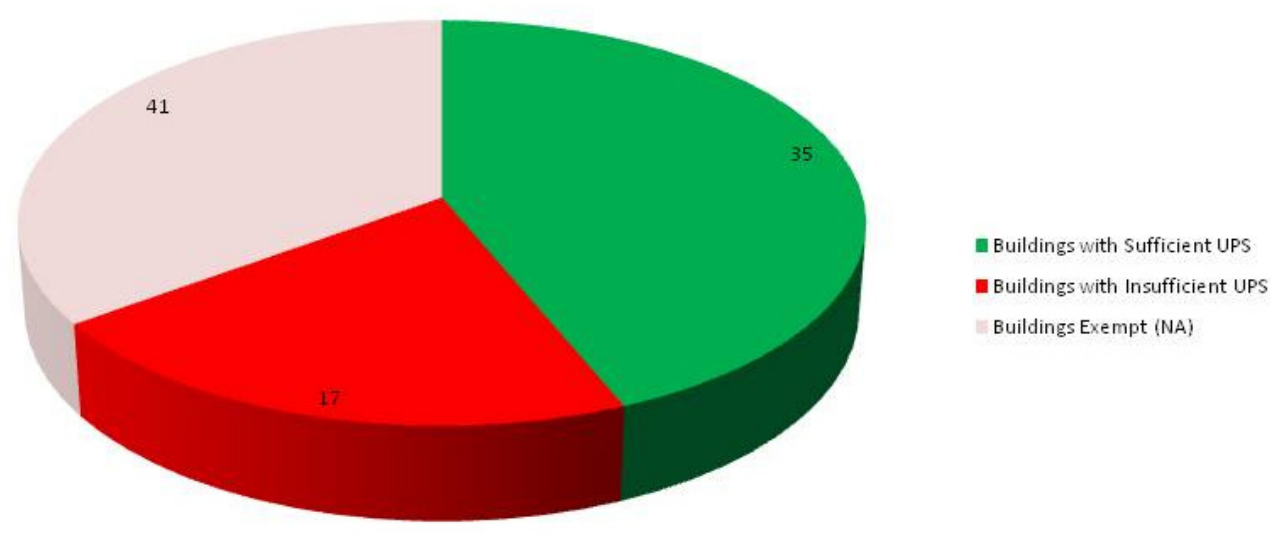

FIGURE 4. STD-170 identifies pathway and space standards. 


\section{MFC Building HVAC Summary}

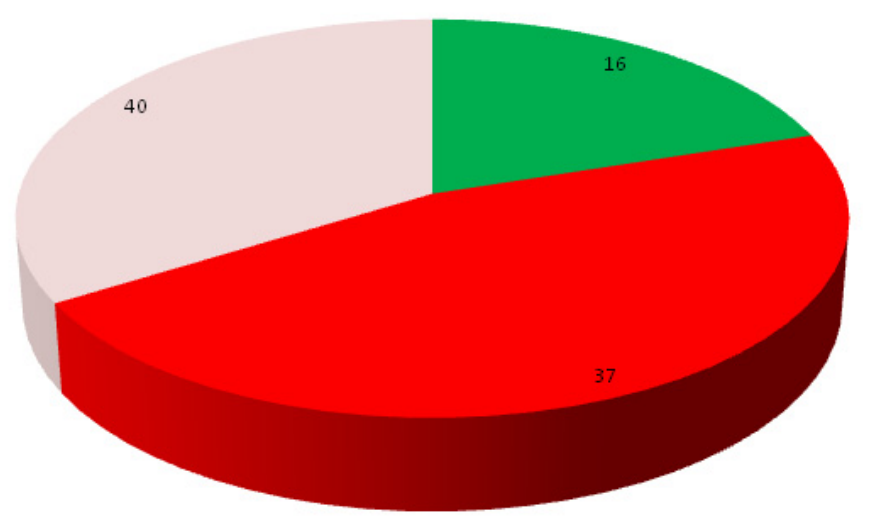

- Buildings with Sufficient HVAC

n Buildings with Insufficient HVAC

Buildings Exempt (NA)

STD-170 identifies Environmental Control (HVAC)

FIgURE 5. MFC Building HVAC Summary.

\section{MFC Building Space Summary}

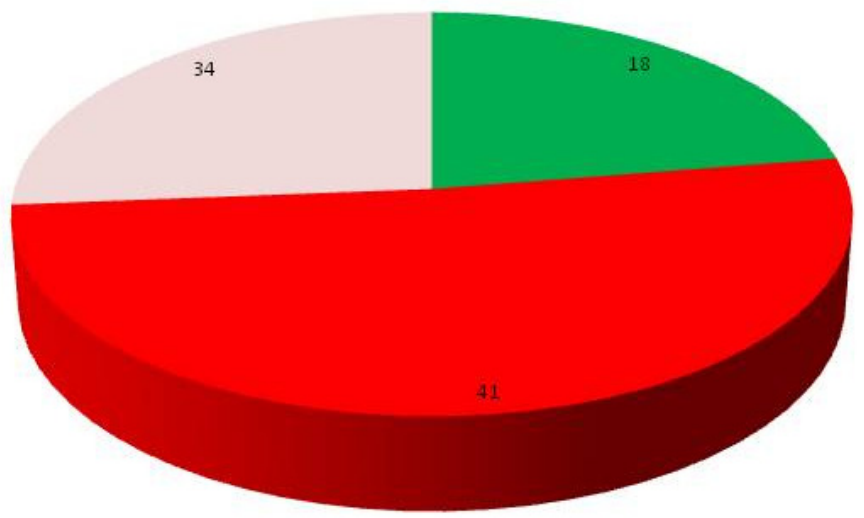

Muildings with Sufficient Space

- Buildings with Insufficient Space

Buildings Exempt (NA)

FIGURE 6. STD-170 identifies pathway and space standards. 
The MFC campus has a mixture of conduit pathway configurations. STD-170 specifies that conduit shall be a minimum of 4 inches to allow for growth and usability. The following chart is a summary of the conduit duct bank identified on the MFC campus drawing. Approximately 30 duct-bank routes are used to connect building entry conduits.

\section{MFC Campus Conduit Summary}

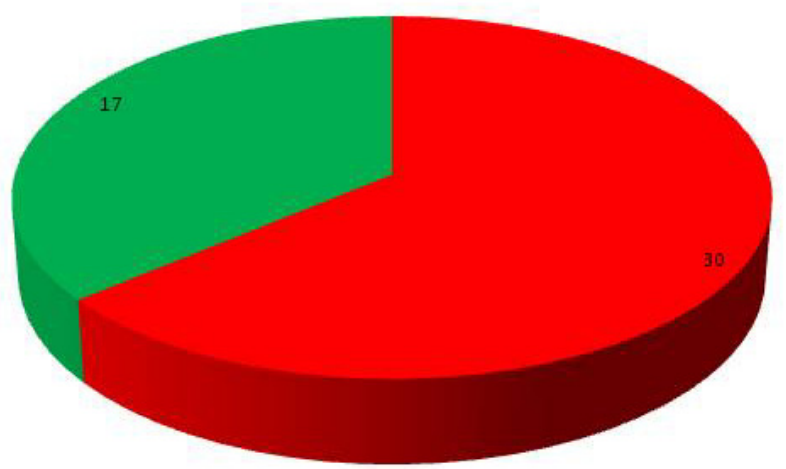

- Buildings/Locations with 2 " or less Conduit

= Buildings/Locations with 4 " Conduit

FIGURE 7. STD-170 identifies pathway standards.

Building with Power over Ethernet (PoE)

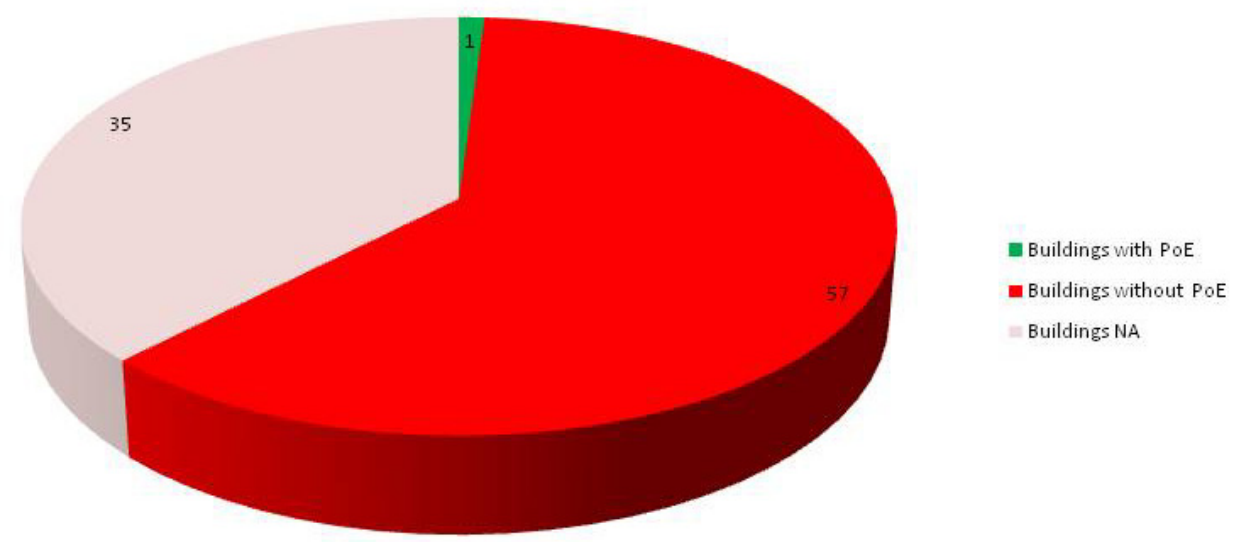

FIGURE 8. Power over Ethernet is required for VoIP. 


\subsection{MFC Building Data Port Availability Bar Graph}

The following chart displays the total number of data ports and how many ports are currently available. Only those facilities that have data connectivity are represented. A facility may be served by two or more telecommunications rooms. In these cases, the number of ports for each telecommunications room is represented. The bar graph is a snapshot in time and represents data as of September 2011. The data is dynamic and changes frequently as new services are deployed to customers. 


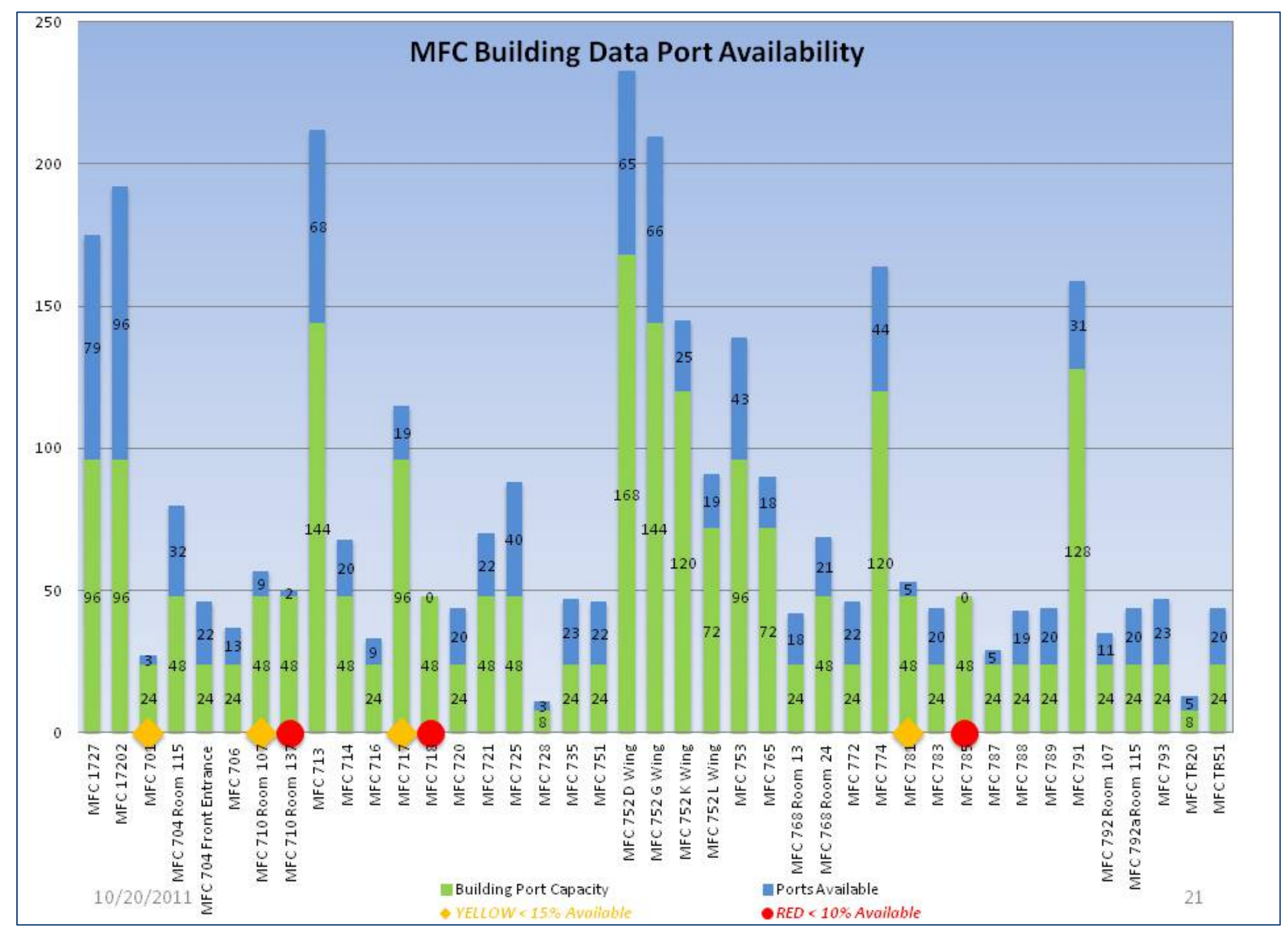




\subsection{Current MFC Multimedia/Video Conference Room Capability Summary}

Additionally, video conferencing and multimedia presentation capabilities were assessed at MFC. The video conferencing and multimedia standard provides direct support and helps advance INL missions, objectives, programs and projects. Video conferencing and multimedia supports all laboratory stakeholders including internal INL Lines-of-Business such as Administrative, Business and Financial, Communications, Education, Engineering, Human Resources, National \& Homeland Security, Nuclear Operations, Research \& Development, Counterintelligence, Supply Chain, Training, and Technology Transfer. Other stakeholders include the Global Nuclear Energy Partnership, Spent Nuclear Fuels, Advanced Fuel Cycle Initiative, and Work for Others (WFOs).

Seamless uninterrupted video conferences and multimedia presentations are required by program offices to help promote INL professional and industry image. The current non-standard multimedia and video conferencing capabilities at INL experience failed, delayed, or lost connections on a consistent basis. This can be alleviated by using standard high-quality multimedia equipment in conference rooms, as well as the room-based video conferencing.

A standard implementation will make the end user experience consistent in conducting presentations. Video conferencing reduces travel cost for meetings. Below is a brief summary of the infrastructure that is available.

- $\quad$ MFC-752, L\&O, Room K102 and MFC-713, Room 111 both include a video conference system, but have limited multimedia (audio/video) capability

- MFC-752, Room F101 has a complete multimedia (audio/video) system with no video capability

- MFC-725, Fire Station, has a complete multimedia (audio/video) and complete video capability.

\section{ASSESSMENT DEFICIENCIES}

The physical assessment and the review of campus Drawing No. 438192 provided the raw data input for the communications study team for analysis to develop a list of deficiencies that are summarized in the following two categories, Campus \& Building (see Appendix B).

Current MFC Campus Deficiencies:

- OSP site/campus feeder fiber capacity associated to MH50 (see Appendix D)

- Insufficient inter-campus/intra-campus fiber capacity

- Conduit/MH capacity

- Pathways routing through building verses duct

- Voice services at capacity

- $\quad$ Limited multimedia video capabilities.

Current MFC Building Deficiencies:

- Non-standard fiber and Cat 6A cabling

- Insufficient HVAC

- Insufficient UPS (backup power)

- Insufficient space (including square footage, security, access, growth, voltage issues, and inadequate conduit). 


\section{PROPOSED RECOMMENDATIONS IN PRIORITY ORDER}

NOTE: Though other priorities exist, those listed in Table 3 are highest level priorities taking precedence over all other priorities.

\begin{tabular}{|c|c|c|c|c|}
\hline $\begin{array}{l}\text { Proposed MFC } \\
\text { Communications } \\
\text { Infrastructure } \\
\text { Projects }\end{array}$ & Description & Status & Appendix & Recommendation \\
\hline $\begin{array}{l}\text { MH50 fiber } \\
\text { reinforcement }\end{array}$ & $\begin{array}{l}\text { Install new } 48 \text {-fiber single } \\
\text { mode cable from MH50 to } \\
\text { MFC-1728. MH50 } \\
\text { reconfiguration needs to } \\
\text { be completed to correct } \\
\text { this deficiency. } \\
\text { Fibers from INL } \\
\text { Administration Building } \\
\text { (IAB) can be reconfigured } \\
\text { to enhance MFC } \\
\text { connectivity. }\end{array}$ & $\begin{array}{l}\text { Institutional } \\
\text { General Plant } \\
\text { Project (iGPP) } \\
\text { project } \\
\text { submitted and } \\
\text { listed in } \\
\text { Appendix B, } \\
\text { TYSP }\end{array}$ & $\mathrm{D}$ & 1 \\
\hline $\begin{array}{l}\text { MFC-752S OSP } \\
\text { alternate path }\end{array}$ & $\begin{array}{l}\text { Install new duct bank } \\
\text { bypassing MFC- } 752 \text {. }\end{array}$ & $\begin{array}{l}\text { Need formal } \\
\text { cost estimate }\end{array}$ & $\mathrm{D}$ & 2 \\
\hline $\begin{array}{l}\text { MFC } \\
\text { MH5-HH/MH1 }\end{array}$ & $\begin{array}{l}\text { Install new duct bank } \\
\text { route. }\end{array}$ & $\begin{array}{l}\text { Need formal } \\
\text { cost estimate }\end{array}$ & D & 3 \\
\hline $\begin{array}{l}\text { Building } \\
\text { infrastructure } \\
\text { upgrades (Nuc and } \\
\text { non-Nuc) }\end{array}$ & $\begin{array}{l}\text { Upgrade building } \\
\text { infrastructure to STD-170 } \\
\text { requirements based on } \\
\text { mission need and } \\
\text { programmatic support. }\end{array}$ & $\begin{array}{l}\text { iGPP project } \\
\text { submitted (see } \\
\text { Appendix B }\end{array}$ & B & 4 \\
\hline $\begin{array}{l}\text { Multimedia/video } \\
\text { conferencing }\end{array}$ & $\begin{array}{l}\text { Enable multimedia } \\
\text { capabilities in all } \\
\text { conference rooms and } \\
\text { video conferencing, as } \\
\text { required. }\end{array}$ & $\begin{array}{l}\text { iGPP project } \\
\text { submitted (see } \\
\text { Appendix B) }\end{array}$ & N/A & 5 \\
\hline
\end{tabular}

\section{NEXT STEPS}

- Implement the manhole and pathway infrastructure plan recommendations.

- A formal cost estimate and IPL is in place for MH50. Assign project manager and fund construction.

- A formal cost estimate is needed for MH5-HH1 duct bank route.

- Prioritize MFC buildings plan based on customer requirements that address building issues (e.g., cabling) and outside plant infrastructure issues (e.g., conduit, manholes, fiber/copper, pathways) based on programmatic requirements, lab mission, and funding.

- Prioritize video conference capability needs based on programmatic requirements. A formal cost estimate and IPL is in place as an enterprise upgrade including MFC. 


\section{Appendix A \\ Contributors and TPOC's}

1. Michael Cannon (Lead)

2. Susan Gihring

3. Gary Cook

4. George Danklefsen

5. Paul Fairbourn

6. Lisa Stearns

7. Terry Barney 


\section{Appendix B MFC Communications Study by Building Summary}

Recommendation No. 4 is building infrastructure upgrades based on STD-170 and driven by mission need and programmatic support. Facility status can be derived from the following charts. 


\begin{tabular}{|c|c|c|c|c|c|c|c|c|c|c|}
\hline \multirow{3}{*}{$\begin{array}{c}\text { Building } \\
\#\end{array}$} & \multirow[b]{2}{*}{ Fiber } & \multirow{2}{*}{\multicolumn{3}{|c|}{ Copper }} & \multirow{2}{*}{$\begin{array}{c}\text { Voice / } \\
\text { Data }\end{array}$} & UPS & HVAC & Space & \multirow{3}{*}{$\begin{array}{l}\text { As Built } \\
\text { Drawing }\end{array}$} & \multirow[b]{2}{*}{ PoE } \\
\hline & & & & & & \multicolumn{3}{|c|}{ (Sufficient) } & & \\
\hline & & Cat 3 & Cat 5 & Cat $6 / 6 a$ & & & & & & \\
\hline $\begin{array}{l}701 \\
\text { Data Cabinet }\end{array}$ & $\begin{array}{l}\text { Yes } \\
\text { (MM) }\end{array}$ & Yes & Yes & & Yes & No & No & No & & No \\
\hline $\begin{array}{l}701 \\
\text { Voice Cabinet }\end{array}$ & No & Yes & Yes & & $\begin{array}{l}\text { Voice } \\
\text { only }\end{array}$ & NA & No & Yes & $\begin{array}{l}765001,774494 \\
765001\end{array}$ & NA \\
\hline $\begin{array}{l}702,703 \\
\text { Storage }\end{array}$ & NA & NA & NA & NA & NA & NA & NA & NA & NA & NA \\
\hline $\begin{array}{l}704 \\
\text { Room } 3 \\
\text { Secured area }\end{array}$ & No & $\begin{array}{l}\text { Yes } \\
66 \\
\text { block }\end{array}$ & $\begin{array}{l}\text { Yes } \\
66 \\
\text { block }\end{array}$ & & Yes & Yes & Yes & Yes & 762799,762294 & No \\
\hline $\begin{array}{l}704 \\
\text { Vault Escort } \\
\text { required }\end{array}$ & $\begin{array}{l}\text { Yes } \\
\text { (MM) }\end{array}$ & No & Yes & & Data & No & No & No & & No \\
\hline $\begin{array}{l}706 \\
\text { Utility }\end{array}$ & $\begin{array}{l}\text { Yes } \\
\text { (MM) }\end{array}$ & Yes & yes & & Yes & Yes & No & No & & No \\
\hline $\begin{array}{l}707 \\
\text { Pump house }\end{array}$ & NA & NA & NA & NA & NA & NA & NA & NA & NA & NA \\
\hline $\begin{array}{l}709 \\
\text { Escort } \\
\text { needed }\end{array}$ & No & $\begin{array}{l}\text { Yes } \\
66 \\
\text { block }\end{array}$ & No & & $\begin{array}{l}\text { Voice } \\
\text { only }\end{array}$ & NA & NA & NA & NA & NA \\
\hline $\begin{array}{l}710 \\
\text { Room } 107\end{array}$ & $\begin{array}{l}\text { Yes } \\
\text { (MM) }\end{array}$ & Yes & Yes & & Yes & Yes & No & No & 764996,759842 & No \\
\hline $\begin{array}{l}710 \\
\text { Room } 137\end{array}$ & $\begin{array}{l}\text { Yes } \\
\text { (MM) }\end{array}$ & Yes & Yes & & Yes & Yes & No & No & & No \\
\hline
\end{tabular}




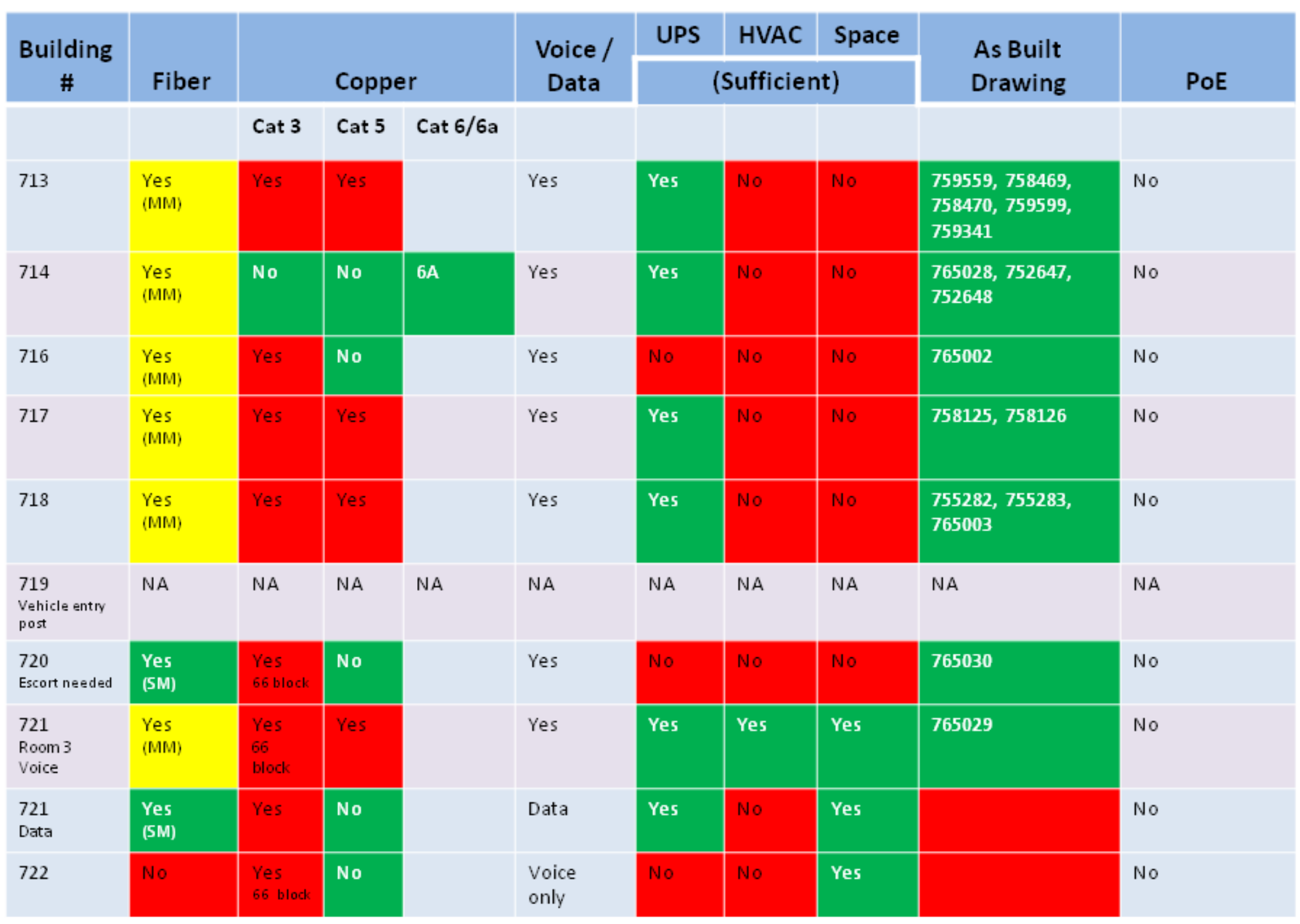




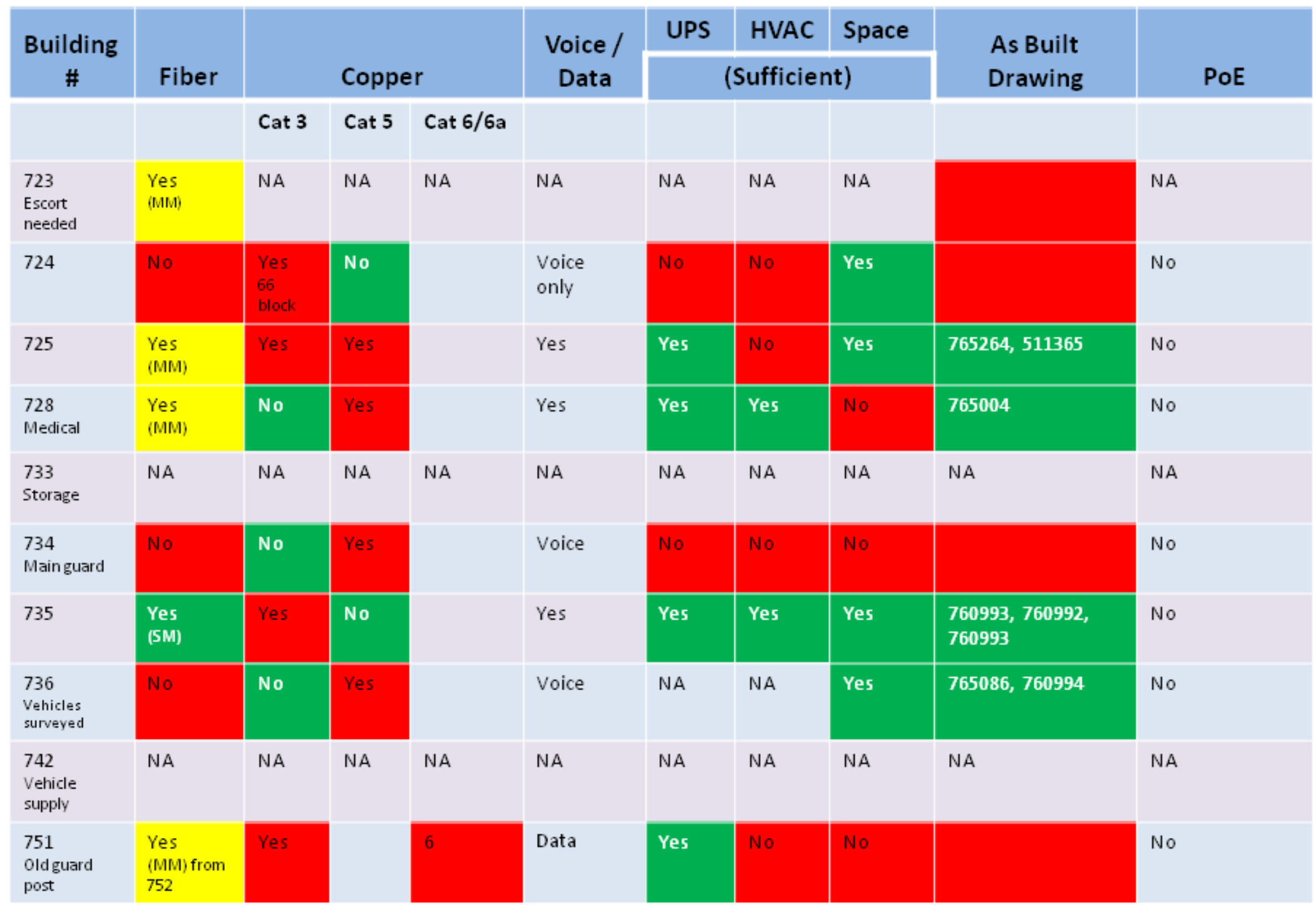




\begin{tabular}{|c|c|c|c|c|c|c|c|c|c|c|}
\hline \multirow{3}{*}{$\begin{array}{c}\text { Building } \\
\#\end{array}$} & \multirow{3}{*}{ Fiber } & & & & Voice / & UPS & HVAC & Space & \multirow{3}{*}{$\begin{array}{l}\text { As Built } \\
\text { Drawing }\end{array}$} & \multirow[b]{2}{*}{ PoE } \\
\hline & & \multicolumn{3}{|c|}{ Copper } & Data & \multicolumn{3}{|c|}{ (Sufficient) } & & \\
\hline & & Cat 3 & Cat 5 & Cat $6 / 6 a$ & & & & & & \\
\hline $\begin{array}{l}752 \\
\text { G wing Room } \\
102\end{array}$ & $\begin{array}{l}\text { Yes } \\
\text { (MM) }\end{array}$ & Yes & No & $6 A$ & Yes & No & No & Yes & & No \\
\hline $\begin{array}{l}752 \\
\text { G wing } \\
\text { Room } 109\end{array}$ & $\begin{array}{l}\text { Yes } \\
(\mathrm{MM})\end{array}$ & Yes & Yes & & yes & Yes & No & No & & No \\
\hline $\begin{array}{l}752 \\
\text { Lwing (D at a) }\end{array}$ & $\begin{array}{l}\text { Yes } \\
\text { (MM) }\end{array}$ & Yes & Yes & 6 & $\begin{array}{l}\text { Data } \\
\text { only }\end{array}$ & Yes & No & No & & No \\
\hline $\begin{array}{l}752 \\
\text { L wing Voice }\end{array}$ & $\begin{array}{l}\text { Yes } \\
\text { (MM) }\end{array}$ & Yes & Yes & & Yes & Yes & Yes & No & & No \\
\hline $\begin{array}{l}752 \\
\text { Main }\end{array}$ & $\begin{array}{l}\text { Yes } \\
\text { (MM) }\end{array}$ & Yes & Yes & 6 & Yes & Yes & Yes & Yes & & No \\
\hline $\begin{array}{l}752 \\
\text { Basement }\end{array}$ & No & Yes & No & & $\begin{array}{l}\text { Voice } \\
\text { only }\end{array}$ & Yes & Yes & Yes & & No \\
\hline $\begin{array}{l}752 \\
\text { Library }\end{array}$ & No & Yes & Yes & & $\begin{array}{l}\text { Voice } \\
\text { only }\end{array}$ & Yes & No & Yes & & No \\
\hline 753 & $\begin{array}{l}\text { Yes } \\
\text { (MM) }\end{array}$ & Yes & Yes & & Yes & Yes & Yes & No & $\begin{array}{l}765087,758857 \\
758858,765087\end{array}$ & No \\
\hline $\begin{array}{l}754,758 \\
\text { Substation }\end{array}$ & No & Yes & No & & Yes & NA & NA & NA & 631777 & NA \\
\hline $\begin{array}{l}756 \\
\text { Pump House }\end{array}$ & NA & NA & NA & NA & NA & NA & NA & NA & NA & NA \\
\hline 759 & $\begin{array}{l}\text { Yes } \\
\text { (MM) }\end{array}$ & $\begin{array}{l}\text { Yes } \\
66 \\
\text { block }\end{array}$ & No & & $\begin{array}{l}\text { Voice } \\
\text { only }\end{array}$ & Yes & No & No & 765027 & No \\
\hline
\end{tabular}




\begin{tabular}{|c|c|c|c|c|c|c|c|c|c|c|}
\hline \multirow{3}{*}{$\begin{array}{c}\text { Building } \\
\text { \# }\end{array}$} & \multirow{3}{*}{ Fiber } & \multirow{2}{*}{\multicolumn{3}{|c|}{ Copper }} & \multirow{3}{*}{$\begin{array}{c}\text { Voice / } \\
\text { Data }\end{array}$} & UPS & HVAC & Space & \multirow{3}{*}{$\begin{array}{l}\text { As Built } \\
\text { Drawing }\end{array}$} & \multirow{3}{*}{ PoE } \\
\hline & & & & & & \multicolumn{3}{|c|}{ (Sufficient) } & & \\
\hline & & Cat 3 & Cat 5 & Cat 6/6a & & & & & & \\
\hline $\begin{array}{l}760 \\
\text { Pump House }\end{array}$ & NA & NA & NA & NA & NA & NA & NA & NA & NA & NA \\
\hline $\begin{array}{l}765 \\
\text { Basement } \\
\text { Escort needed }\end{array}$ & $\begin{array}{l}\text { Yes } \\
\text { (MM) }\end{array}$ & Yes & Yes & & $\begin{array}{l}\text { Voice } \\
\text { only }\end{array}$ & NA & NA & No & & No \\
\hline $\begin{array}{l}765 \\
\text { Data }\end{array}$ & $\begin{array}{l}\text { Yes } \\
\text { (MM) }\end{array}$ & Yes & No & & $\begin{array}{l}\text { Data } \\
\text { only }\end{array}$ & No & No & No & & No \\
\hline $\begin{array}{l}766 \\
\text { RAD area }\end{array}$ & NA & NA & NA & NA & NA & NA & NA & NA & NA & NA \\
\hline $\begin{array}{l}767 \\
\text { Demolition } \\
\text { Bldg. }\end{array}$ & NA & NA & NA & NA & $\begin{array}{l}\text { Voice } \\
\text { only }\end{array}$ & NA & NA & NA & NA & NA \\
\hline $\begin{array}{l}768 \\
3^{\text {dd }} \text { floor }\end{array}$ & $\begin{array}{l}\text { Yes } \\
\text { (SM) }\end{array}$ & Yes & Yes & & Yes & Yes & No & No & & No \\
\hline $\begin{array}{l}768 \\
\text { Main }\end{array}$ & No & $\begin{array}{l}\text { Yes } \\
66 \text { block }\end{array}$ & No & & $\begin{array}{l}\text { Voice } \\
\text { only }\end{array}$ & NA & NA & No & 765084 & No \\
\hline $\begin{array}{l}768 \\
2^{\text {nd floor }}\end{array}$ & $\begin{array}{l}\text { Yes } \\
\text { (MM) }\end{array}$ & Yes & Yes & & Data & No & No & No & & No \\
\hline $\begin{array}{l}769 \\
\text { Storagefor } \\
\text { compressed } \\
\text { gas }\end{array}$ & NA & NA & NA & NA & NA & NA & NA & NA & NA & NA \\
\hline $\begin{array}{l}770 \\
\text { Storage \& } \\
\text { pump house }\end{array}$ & NA & NA & NA & NA & NA & NA & NA & NA & NA & NA \\
\hline
\end{tabular}




\begin{tabular}{|c|c|c|c|c|c|c|c|c|c|c|}
\hline \multirow{3}{*}{$\begin{array}{c}\text { Building } \\
\text { \# }\end{array}$} & \multirow{3}{*}{ Fiber } & \multirow{2}{*}{\multicolumn{3}{|c|}{ Copper }} & \multirow{3}{*}{$\begin{array}{c}\text { Voice / } \\
\text { Data }\end{array}$} & UPS & HVAC & Space & \multirow{3}{*}{$\begin{array}{l}\text { As Built } \\
\text { Drawing }\end{array}$} & \multirow{3}{*}{ PoE } \\
\hline & & & & & & \multicolumn{3}{|c|}{ (Sufficient) } & & \\
\hline & & Cat 3 & Cat 5 & Cat 6/6a & & & & & & \\
\hline 772 & $\begin{array}{l}\text { Yes } \\
\text { (MM) }\end{array}$ & Yes & Yes & & Yes & Yes & Yes & No & & No \\
\hline $\begin{array}{l}774 \\
\text { Zipper }\end{array}$ & $\begin{array}{l}\text { Yes } \\
\text { (MM) }\end{array}$ & Yes & Yes & & Voice only & Yes & Yes & No & 762422 & No \\
\hline $\begin{array}{l}778 \\
\text { LiftStation }\end{array}$ & NA & NA & NA & NA & NA & NA & NA & NA & NA & NA \\
\hline $\begin{array}{l}780 \\
\text { Storage }\end{array}$ & NA & NA & NA & NA & NA & NA & NA & NA & NA & NA \\
\hline 781 & $\begin{array}{l}\text { Yes } \\
\text { (MM) }\end{array}$ & Yes & Yes & & Yes & Yes & No & No & $\begin{array}{l}765091,760995, \\
765071\end{array}$ & No \\
\hline 782 & $\begin{array}{l}\text { Yes } \\
\text { (MM) }\end{array}$ & Yes & Yes & & Yes & Yes & No & No & 761957 & No \\
\hline 783 & $\begin{array}{l}\text { Yes } \\
\text { (SM) }\end{array}$ & Yes & No & & Yes & Yes & No & No & & No \\
\hline $\begin{array}{l}784 \\
\text { Storage } \\
\text { Secured area }\end{array}$ & No & $\begin{array}{l}\text { Yes } \\
66 \\
\text { block }\end{array}$ & No & & $\begin{array}{l}\text { Voice } \\
\text { Only }\end{array}$ & NA & NA & No & & No \\
\hline $\begin{array}{l}785 \\
\text { Basement } \\
\text { RAD area }\end{array}$ & $\begin{array}{l}\text { Yes } \\
\text { (MM) }\end{array}$ & Yes & No & & Yes & Yes & Yes & No & 765108 & No \\
\hline $\begin{array}{l}788 \\
\text { Feedsfrom } \\
\text { W. Wall of } \\
768\end{array}$ & $\begin{array}{l}\text { Yes } \\
\text { (MM) }\end{array}$ & Yes & Yes & & Yes & No & No & No & $\begin{array}{l}752414,752416 \\
760047,752415\end{array}$ & No \\
\hline $\begin{array}{l}789 \\
\text { High bay }\end{array}$ & $\begin{array}{l}\text { Yes } \\
\text { (MM) }\end{array}$ & Yes & No & & Yes & No & No & No & 765109 & No \\
\hline
\end{tabular}




\begin{tabular}{|c|c|c|c|c|c|c|c|c|c|c|}
\hline \multirow{3}{*}{$\begin{array}{c}\text { Building } \\
\text { \# }\end{array}$} & \multirow{3}{*}{ Fiber } & & \multirow{2}{*}{\multicolumn{2}{|c|}{ Copper }} & \multirow{3}{*}{$\begin{array}{c}\text { Voice / } \\
\text { Data }\end{array}$} & UPS & HVAC & Space & \multirow{3}{*}{$\begin{array}{l}\text { As Built } \\
\text { Drawing }\end{array}$} & \multirow[b]{2}{*}{ PoE } \\
\hline & & & & & & \multicolumn{3}{|c|}{ (Sufficient) } & & \\
\hline & & Cat 3 & Cat 5 & Cat 6/6a & & & & & & \\
\hline $\begin{array}{l}790 \\
\text { Nophone or } \\
\text { data }\end{array}$ & NA & NA & NA & NA & $\mathrm{Na}$ & NA & NA & NA & NA & NA \\
\hline 791 & $\begin{array}{l}\text { Yes } \\
\text { (MM) }\end{array}$ & Yes & Yes & & Yes & Yes & No & No & 765005 & No \\
\hline $\begin{array}{l}792 \\
\text { Netcab8 }\end{array}$ & $\begin{array}{l}\text { Yes } \\
\text { (MM) }\end{array}$ & Yes & Yes & & $\begin{array}{l}\text { Data } \\
\text { only }\end{array}$ & Yes & Yes & Yes & 765073,766298 & No \\
\hline $\begin{array}{l}792 \\
\text { Netcab }\end{array}$ & No & Yes & No & & Voice & Yes & Yes & Yes & 765073,766298 & No \\
\hline 793 & No & No & No & & No & No & No & No & 765070 & No \\
\hline 794 & No & Yes & No & & Voice & No & No & No & & No \\
\hline $\begin{array}{l}796 \\
\text { storage }\end{array}$ & NA & NA & NA & NA & NA & NA & NA & NA & NA & NA \\
\hline 798 & No & $\begin{array}{l}\text { Yes } \\
66- \\
\text { block }\end{array}$ & No & & $\begin{array}{l}\text { Voice } \\
\text { Only }\end{array}$ & Yes & Yes & Yes & & No \\
\hline $\begin{array}{l}799 \\
\text { No access }\end{array}$ & No & Yes & No & & Voice & NA & NA & No & & No \\
\hline 1702 & $\begin{array}{l}\text { Yes } \\
\text { (SM) }\end{array}$ & Yes & Yes & 6 & Yes & Yes & Yes & Yes & $\begin{array}{l}763041,763042 \\
763400\end{array}$ & No \\
\hline 1727 & $\begin{array}{l}\text { Yes } \\
\text { (SM) }\end{array}$ & No & No & $6 A$ & Yes & Yes & Yes & Yes & & Yes \\
\hline
\end{tabular}




\begin{tabular}{|c|c|c|c|c|c|c|c|c|c|c|}
\hline \multirow{3}{*}{$\begin{array}{c}\text { Building } \\
\text { \# }\end{array}$} & \multirow{3}{*}{ Fiber } & \multirow{2}{*}{\multicolumn{3}{|c|}{ Copper }} & \multirow{2}{*}{$\begin{array}{c}\text { Voice / } \\
\text { Data }\end{array}$} & UPS & HVAC & Space & \multirow{3}{*}{$\begin{array}{l}\text { As Built } \\
\text { Drawing }\end{array}$} & \multirow[b]{2}{*}{ PoE } \\
\hline & & & & & & \multicolumn{3}{|c|}{ (Sufficient) } & & \\
\hline & & Cat 3 & Cat 5 & Cat 6/6a & & & & & & \\
\hline $\begin{array}{l}\text { Norco } \\
\text { Temp Trailer }\end{array}$ & No & Yes & Yes & & Yes & No & No & No & & No \\
\hline $\mathrm{T} 2 \mathrm{~A}$ & No & Yes & No & & Yes & NA & NA & No & & No \\
\hline $\mathrm{T}-20$ & No & Yes & No & & yes & No & No & No & 795111 & No \\
\hline $\begin{array}{l}\text { Tr. } 17 \\
\text { Storage }\end{array}$ & NA & NA & NA & NA & NA & NA & NA & NA & NA & NA \\
\hline $\operatorname{Tr} .51$ & $\begin{array}{l}\text { Yes } \\
\text { (MM) }\end{array}$ & Yes & Yes & & Yes & No & No & No & & No \\
\hline $\begin{array}{l}\text { Tr. 52, 53, } \\
54,55,56, \\
57,58,59 \\
60,61 \\
\text { CWI- temp }\end{array}$ & NA & NA & NA & NA & NA & NA & NA & NA & NA & NA \\
\hline Tr. 1718 & NA & NA & NA & NA & NA & NA & NA & NA & NA & NA \\
\hline $\begin{array}{l}\text { YMC } \\
\text { Temp trailer }\end{array}$ & NA & NA & NA & NA & NA & NA & NA & NA & NA & NA \\
\hline
\end{tabular}


INTENTIONALLY BLANK 


\section{Appendix C MFC Photographs}


Some photographs representing various deficiencies that were identified in this assessment. Additional supporting photographs that span the entire MFC campus are available.

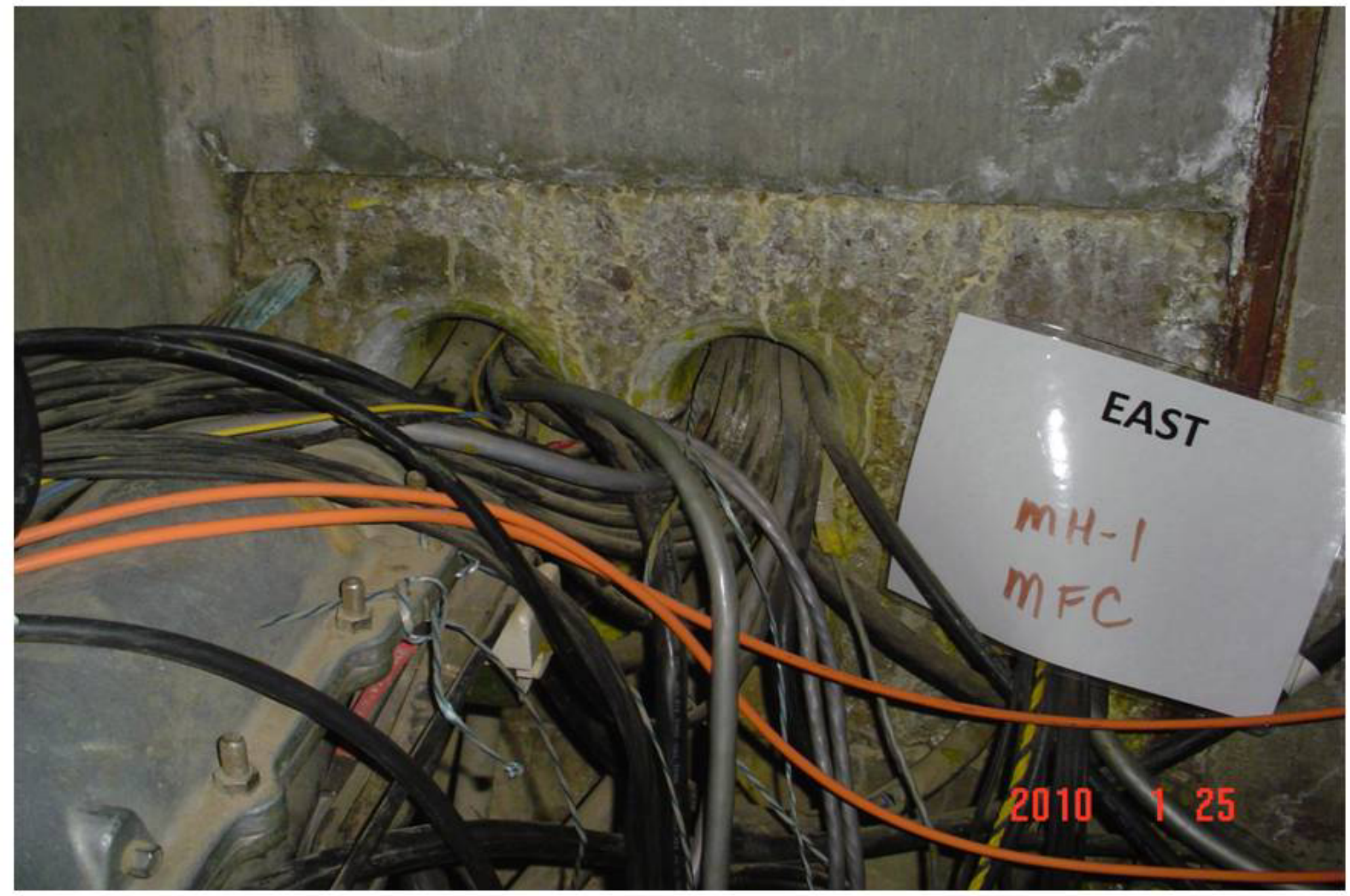

EXAMPLE DEPICTS A MANHOLE AT CAPACITY WITHOUT INNERDUCT 


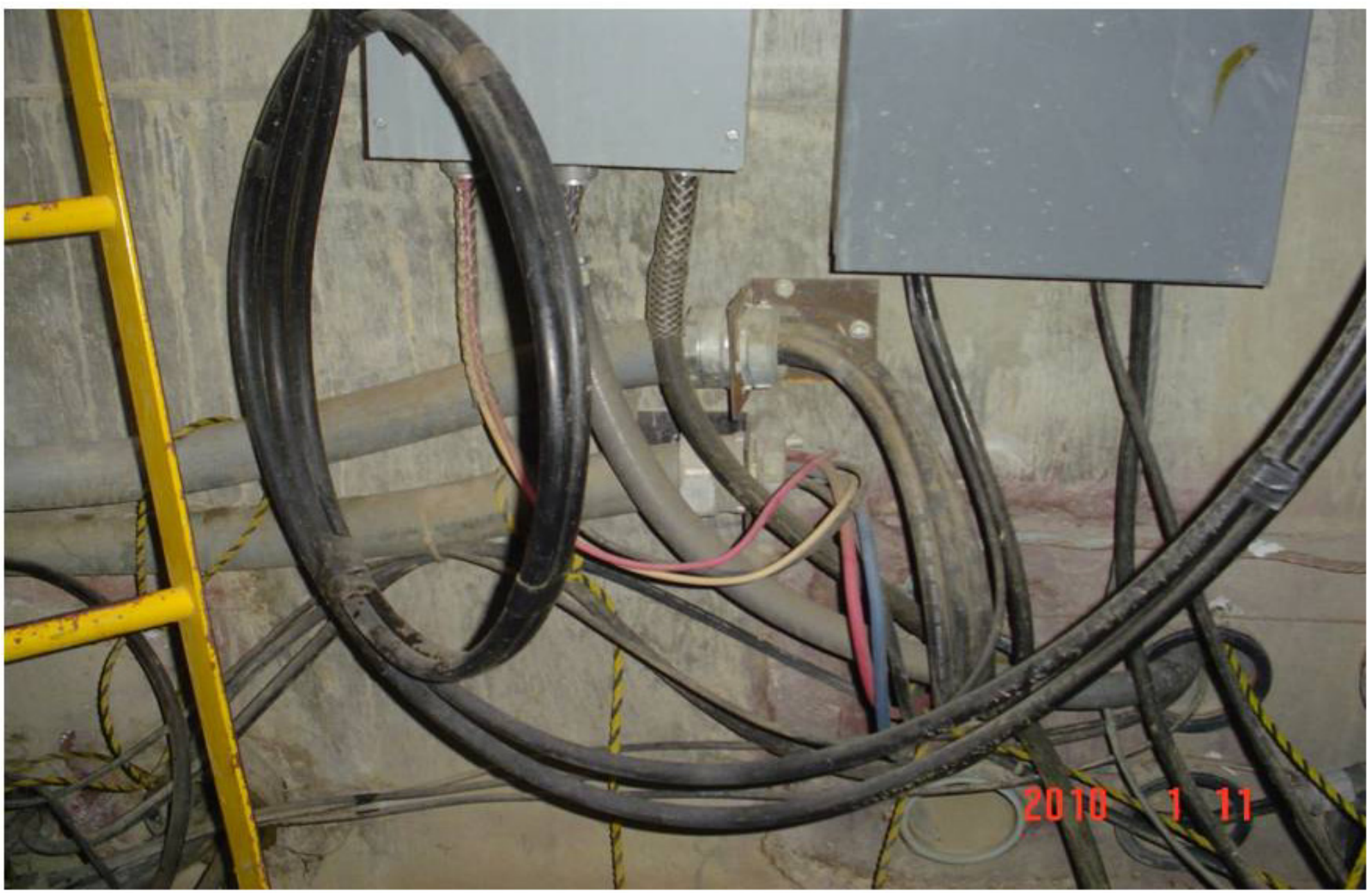

EXAMPLE DEPICTS A SAFETY CONCERN WITH CO-LOCATED HIGH AND LOW VOLTAGE CABLES 
Some photographs representing various deficiencies that were identified in this assessment. Additional supporting photographs that span the entire MFC campus are available.

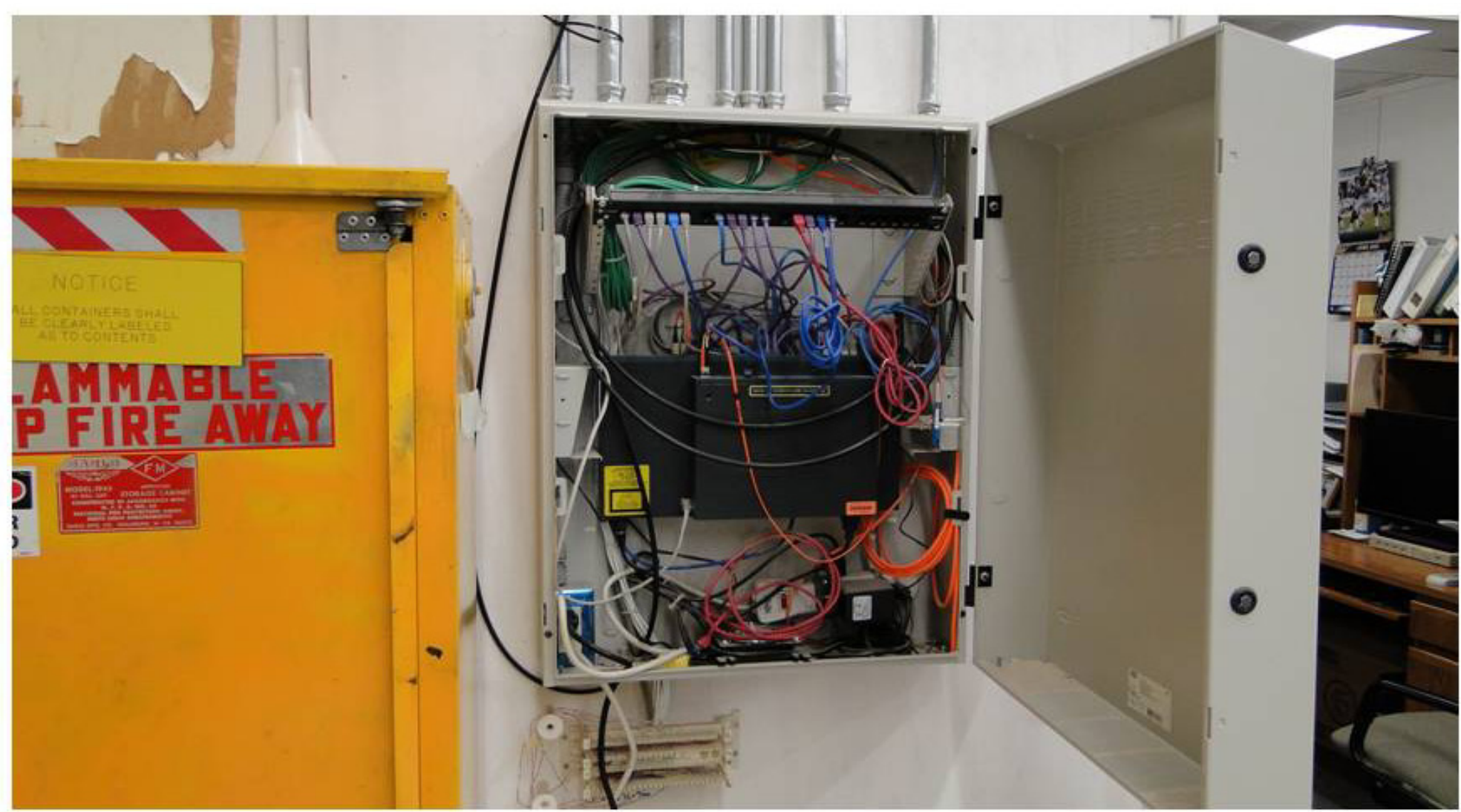

EXAMPLE DEPICTS NONCOMPLIANT UPS AND CABLING AT MFC-788 


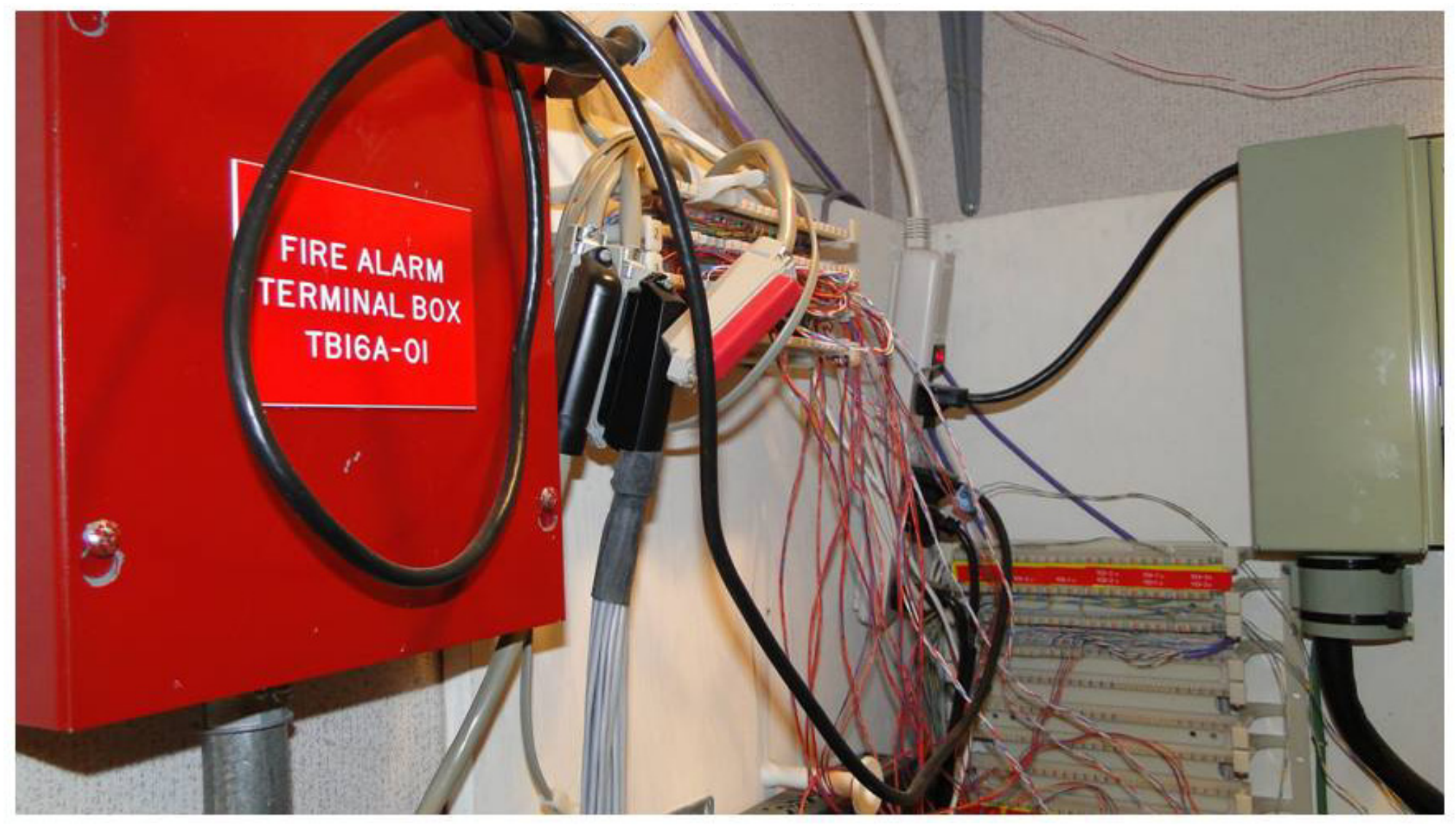

EXAMPLE DEPICTS INSUFFICIENT SPACE AND LACK OF CABLE MANAGEMENT AT MFC-716 
Some photographs representing various deficiencies that were identified in this assessment. Additional supporting photographs that span the entire MFC campus are available.

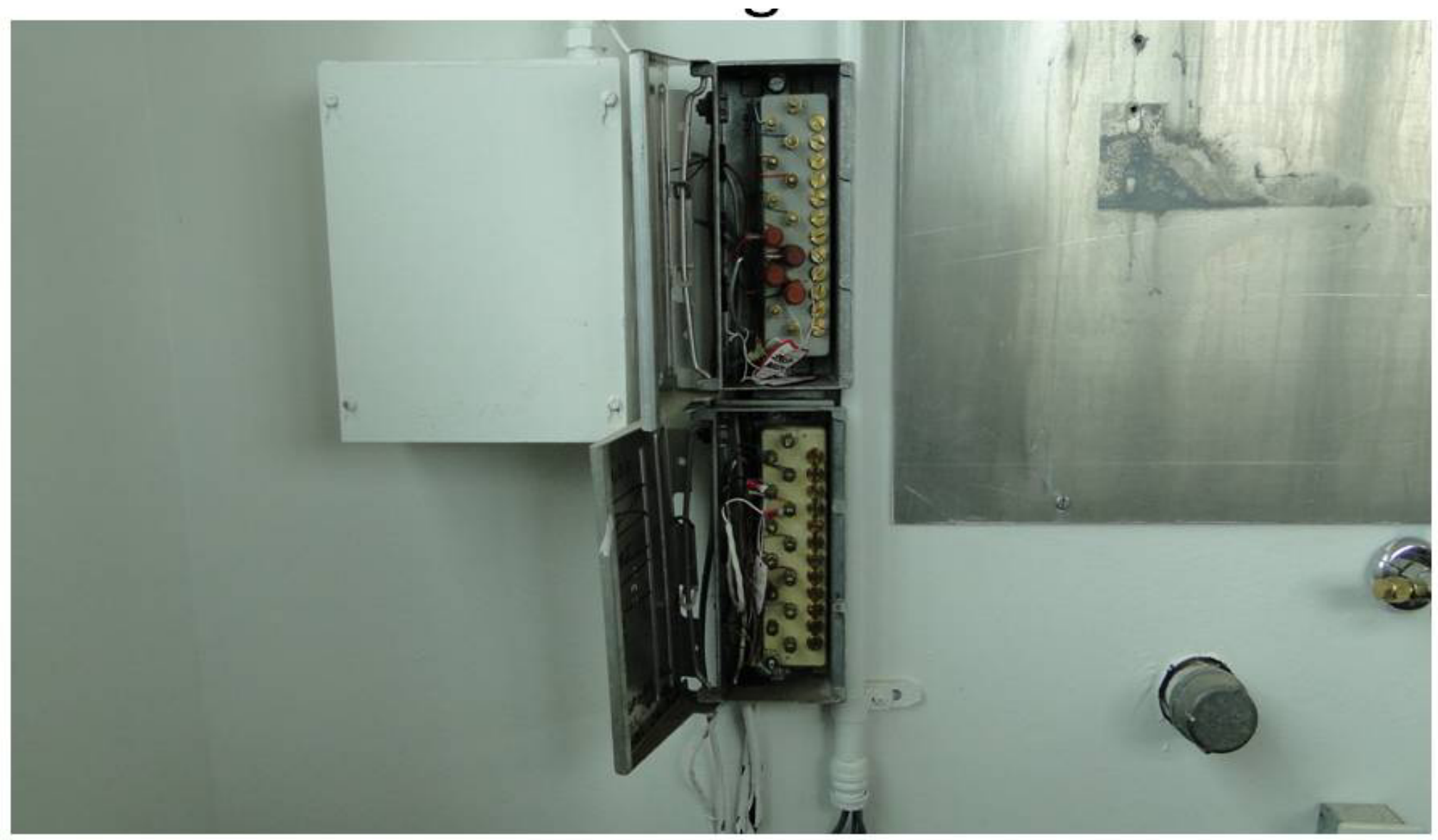

EXAMPLE DEPICTS OUTDATED TECHNOLOGY AND INSUFFICIENT SPACE AT MFC-722 


\section{Appendix D}

\section{MFC Communications Infrastructure Drawings}


INTENTIONALLY BLANK 


\section{MFC Fiber Distribution}

This drawing depicts the total number and type of fiber strands termin ated in MFC facilities. This drawing does not represent the physical pathways of fiber in these facilities, but rather a logical path.

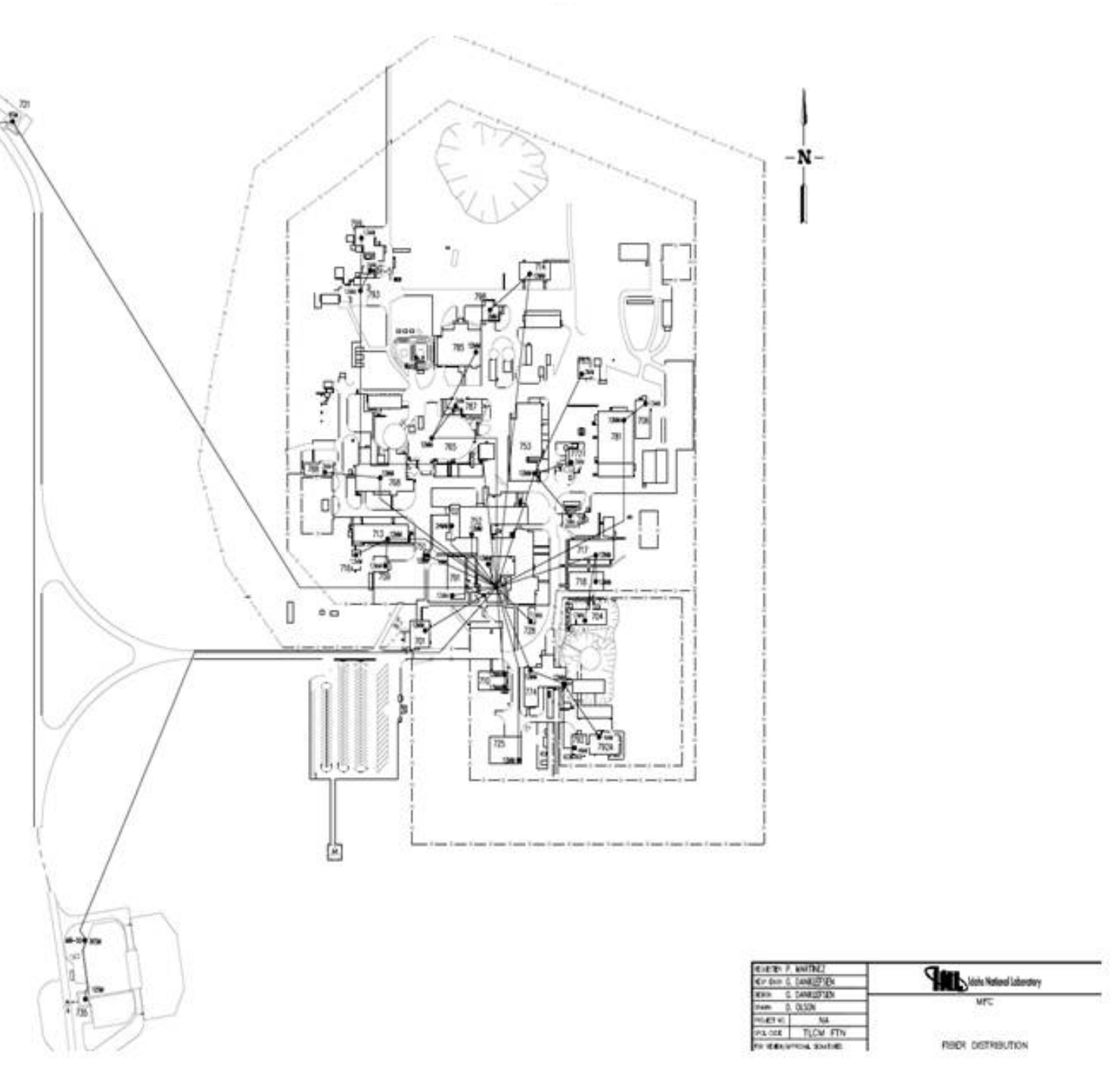


This chart shows fiber distribution throughout the MFC plant.

Red indicates fiber outside multimode fiber specification for distance and performance.

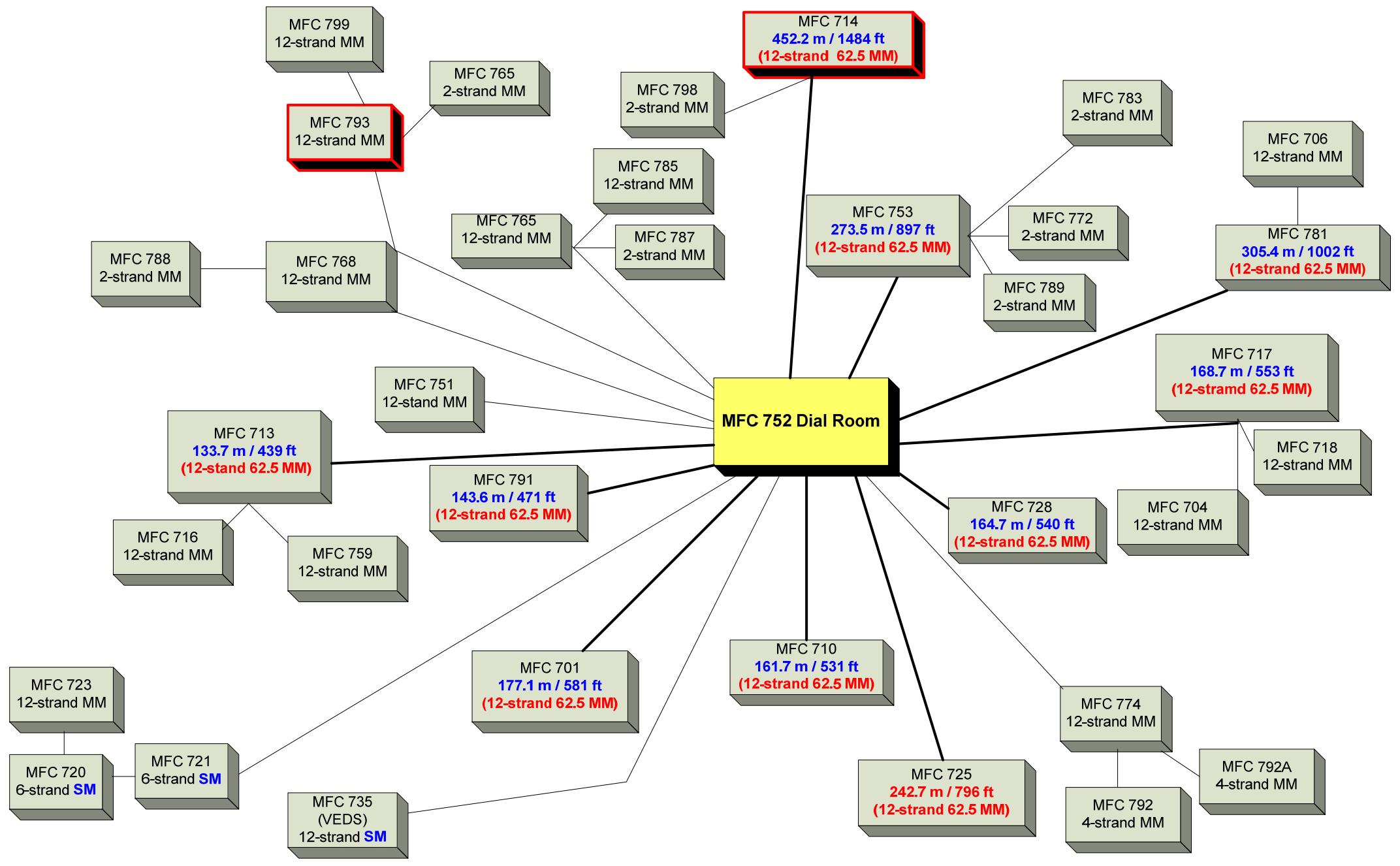




\section{Sketch 1a Purpose/Use}

An integral element of the MFC Communications Infrastructure Study was to update the campus Drawing No. 438192, with sketches 1-a, 1-b, and 1-c. It was used in the assessment to evaluate pathways, manholes, conduit and other campus deficiencies to complete the study and provide a holistic approach to future planning.

1. Drawing No. 438192 - Sketch 1a is a current snapshot of the MFC campus existing OSP routes, pathways, and conduit sizes.

2. Observations:

3. Many pathways do not meet STD-170 requirements

4. There is only one known inner-duct in use at MFC and it feeds from MFC-752 to MFC-1727.

5. Many of the manholes, such as MH1, MH2, MH5, and MH6, are undersized.

6. There are clear co-resident high and low voltage safety issues in manholes associated with the duct/MH infrastructure east of MFC-752 running north-south.

Rather than highlighting all deficiencies regardless of severity, a common sense approach was taken. For example, though MH1 is undersized, replacement is disruptive, costly and unlikely. This section identifies deficiencies that have a significant impact on future development at MFC and can be completed with maximum effect an impact relative to dollars spent. 


\section{Sketch 1a}

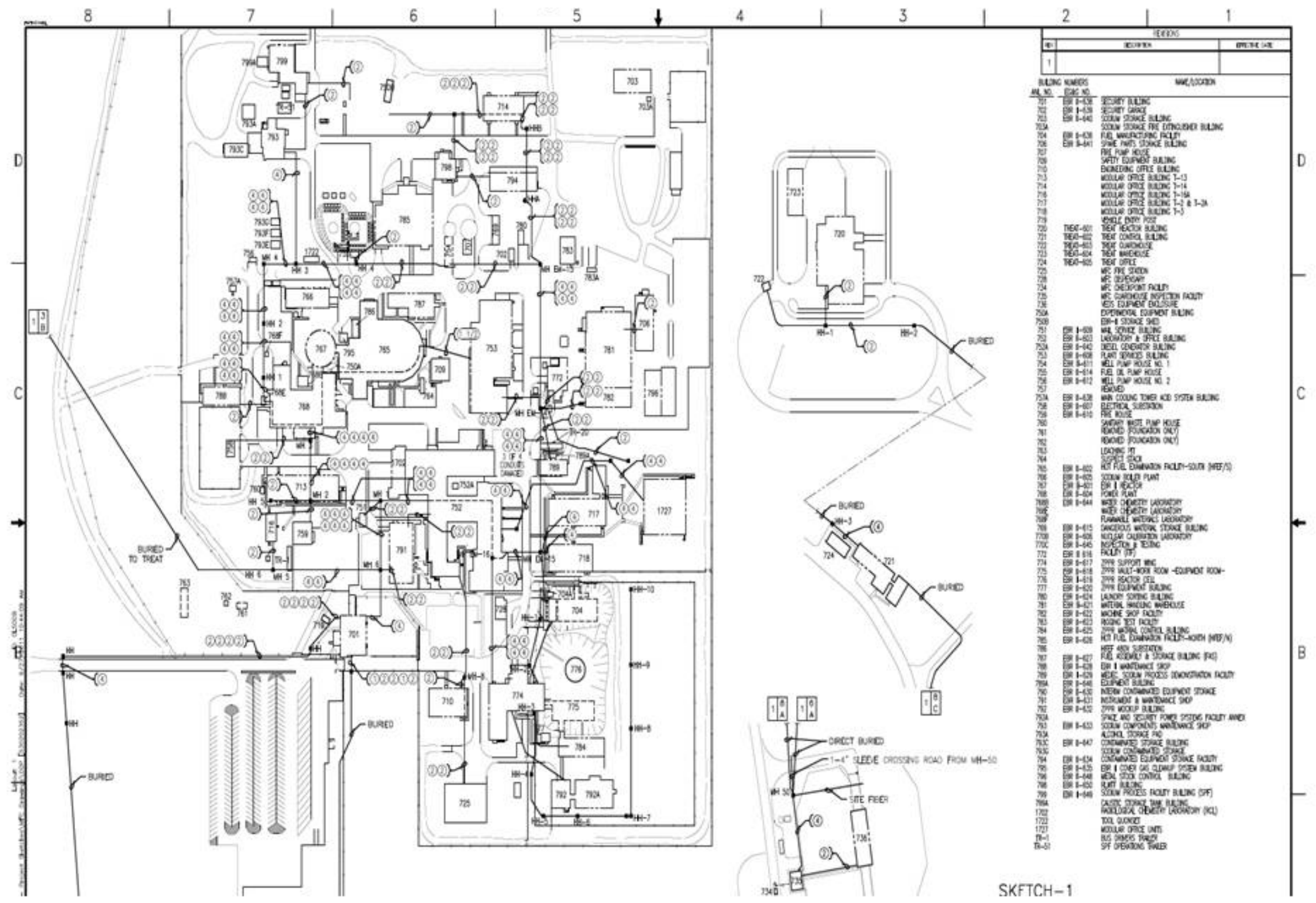




\section{Sketch 1b Purpose/Use}

Drawing No. 438192 - Sketch 1b depicts funded and planned projects overlaid on the current snapshot of OSP routes and pathways. See Appendix E for detailed list of planned projects. These planned projects all meet STD-170 requirements with some minor discrepancies and have the following benefits:

- IMCL/CESB project provides an alternate route for the northeast side of MFC-752 avoiding the co-resident high and low voltage safety concerns present in the existing duct bank route. This does not address the rerouting of cables from the old duct-bank to the new. Working in the old duct bank route manholes will remain a safety concern and activities in these manholes will require a power impairment.

- The dial room project MFC-1728 corrects a major routing deficiency for the inter-site fiber. The fiber will be re-routed from the telecommunications manhole south of MFC-710 through new project installed duct bank directly to MFC-1728. This project will also resolve voice capacity issues and footprint limitations (e.g., no room to add racks) present in MFC-752 that have limited or prevented growth to MFC. It is recommended to avoid routing new cable through MFC-752.

- TSB project provides an alternate route to MFC-1728 avoiding a deficient route through MFC-752. This route will leverage MFC-1728 duct bank to provide the direct route to MFC-1728. Additionally, MH8 pathway is included. 


\section{Sketch 1b}

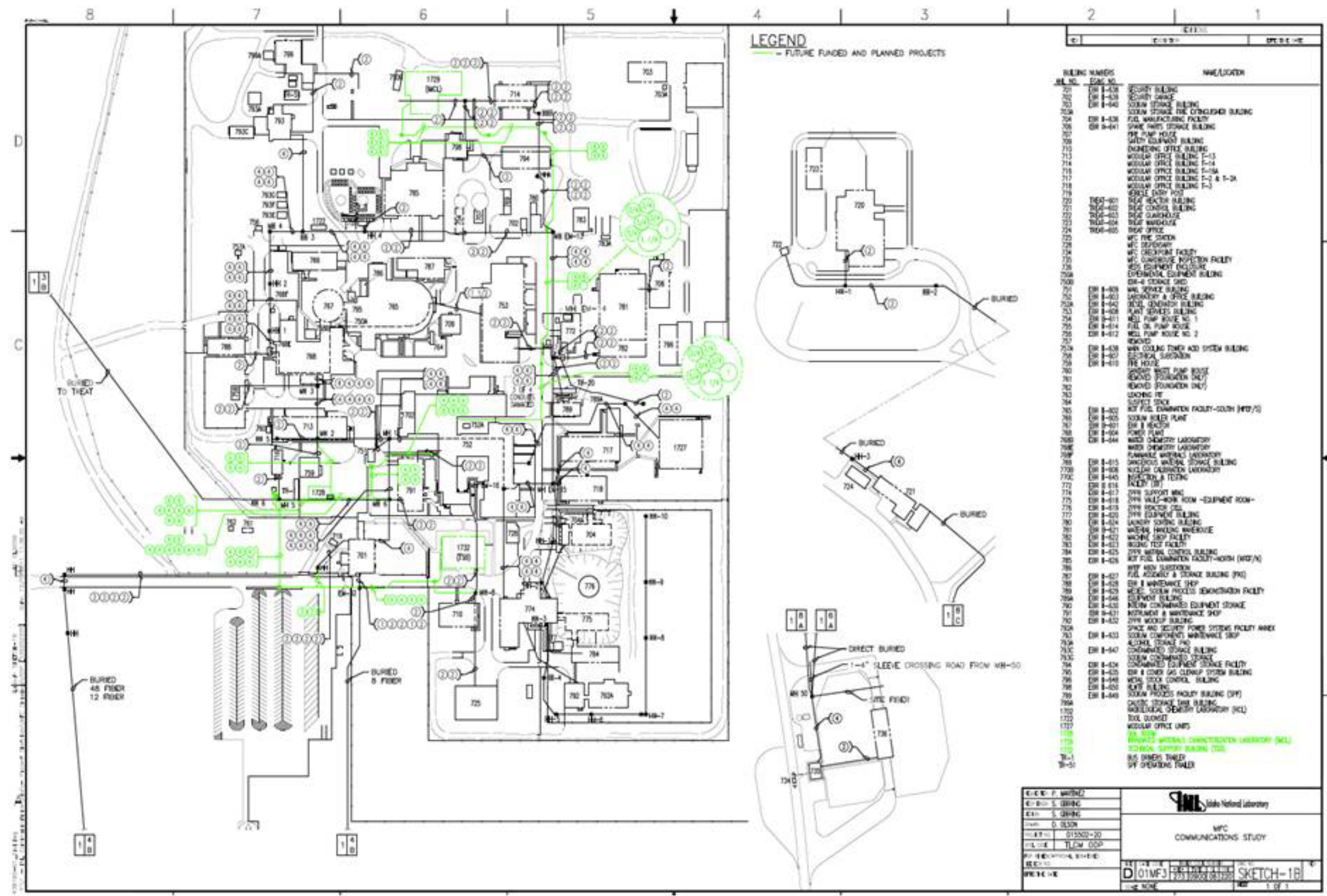




\section{Sketch 1c Purpose/Use}

Drawing No. 438192 sketch 1c and the MH50 detail shows recommendations to increase capacity, resolve safety concerns, provide alternate external routes, and a tie from the southwest plant to the northwest plant. The following recommendations provide the most effect and impact to future capabilities relative to costs.

1. A critical fiber capacity deficiency from MH50 to MFC-752. The 8-strand fiber cable is fully exhausted. Each fiber pair provides transport media for highly scalable platforms. While these platforms serve the needs for MFC external communications, any failure of a single fiber will significantly impact MFC communications capabilities. These platforms provide communications for the Department of Energy (DOE) and CH2M-WG Idaho, LLC (CWI) as well as Battelle Energy Alliance (BEA). Since all eight fibers are in the same splice tray, any failure of a fiber would require a site outage to repair. Additionally two fibers from IAB to CFA will be impacted. The current fiber configuration does not provide for a contingency plan. Eight fibers from CFA are unterminated in MH50. Fibers from IAB can be reconfigured to enhance MFC connectivity. A new 48-fiber single mode cable should be installed from MH50 to MFC-1728. MH50 reconfiguration can then completed to correct this critical deficiency.

2. Install new duct-bank from the last manhole proceeding south to a new manhole at the southeast corner of MFC-752. Intermediate manhole(s) should be considered against TYSP and 30YSP. The new duct-bank should continue south to MFC-774 reinforcing needed security pathways. Additionally from the MFC-752 southeast manhole, duct should continue west to the new dial room MFC-1728. The pathway should be a precast sidewalk similar to the new dial room project to avoid utility congestion. This path will continue down the sidewalk and require trenched duct-bank at the end of the pathway. This recommendation addresses security needs, the avoidance of MFC-752 basement for future east developments, and poses minimal risk to the underground utility-dense area south of MFC-752.

3. A new duct-bank from MH5 to HH/MH1. This duct bank will complete a major pathway deficiency that currently routes through MFC-758 and provide connectivity to MFC-1728 for all future facilities on the west side of the MFC plant.

4. Building infrastructure upgrades based on STD-170 and driven by mission need and programmatic support. 


\section{Sketch 1c Purpose/Use}

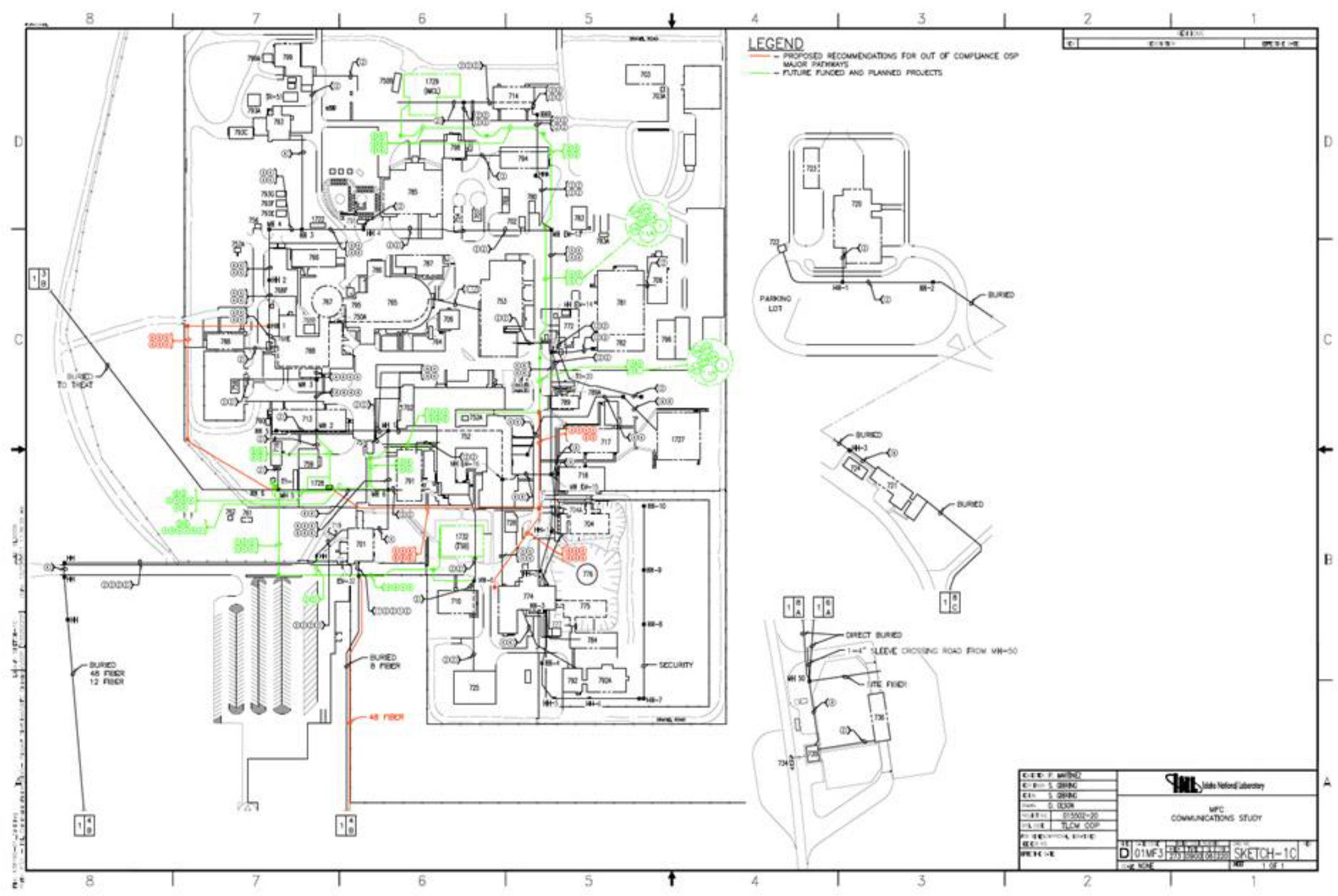




\section{Recommendation 1: Manhole 50 sketch Purpose/Use}

The MH50 sketch addresses the top recommendation for MFC communications infrastructure. A critical fiber capacity deficiency exists from MH50 to MFC-752. The 8-strand cable is fully exhausted. Each fiber pair provides transport media for highly scalable platforms.

\section{Observations:}

This configuration serve the needs for MFC external communications, any failure of a single fiber will significantly impact MFC communications capabilities.

1. These platforms provide communications for DOE and CWI, as well as BEA.

2. All eight fibers are in the same splice tray, any failure of a fiber would require a site outage to repair.

3. Additionally two fibers from IAB to CFA will be impacted. The current fiber configuration does not provide a contingency.

4. Eight fibers from CFA are unterminated in MH50.

\section{Recommendation 1:}

1a. Fibers from IAB can be reconfigured to enhance MFC connectivity.

1b. A new 48-fiber single mode cable should be installed from MH50 to MFC-1728. MH50 reconfiguration needs to be completed to correct this deficiency. 
- 20 fibersfrom CITRC/CFA (4 fusion-spliced to MFC, 8 fusion-spliced to IAB, 8 spare

fibers are unterminated

- 12 fibersfrom IAB(4 fusionsliced to MFC, 8 fusion-spliced to CFA)

- 8 fibersfrom MFCl4 ea

fusion-spliced to IAB and CFA

\section{Recommendation No. 1}

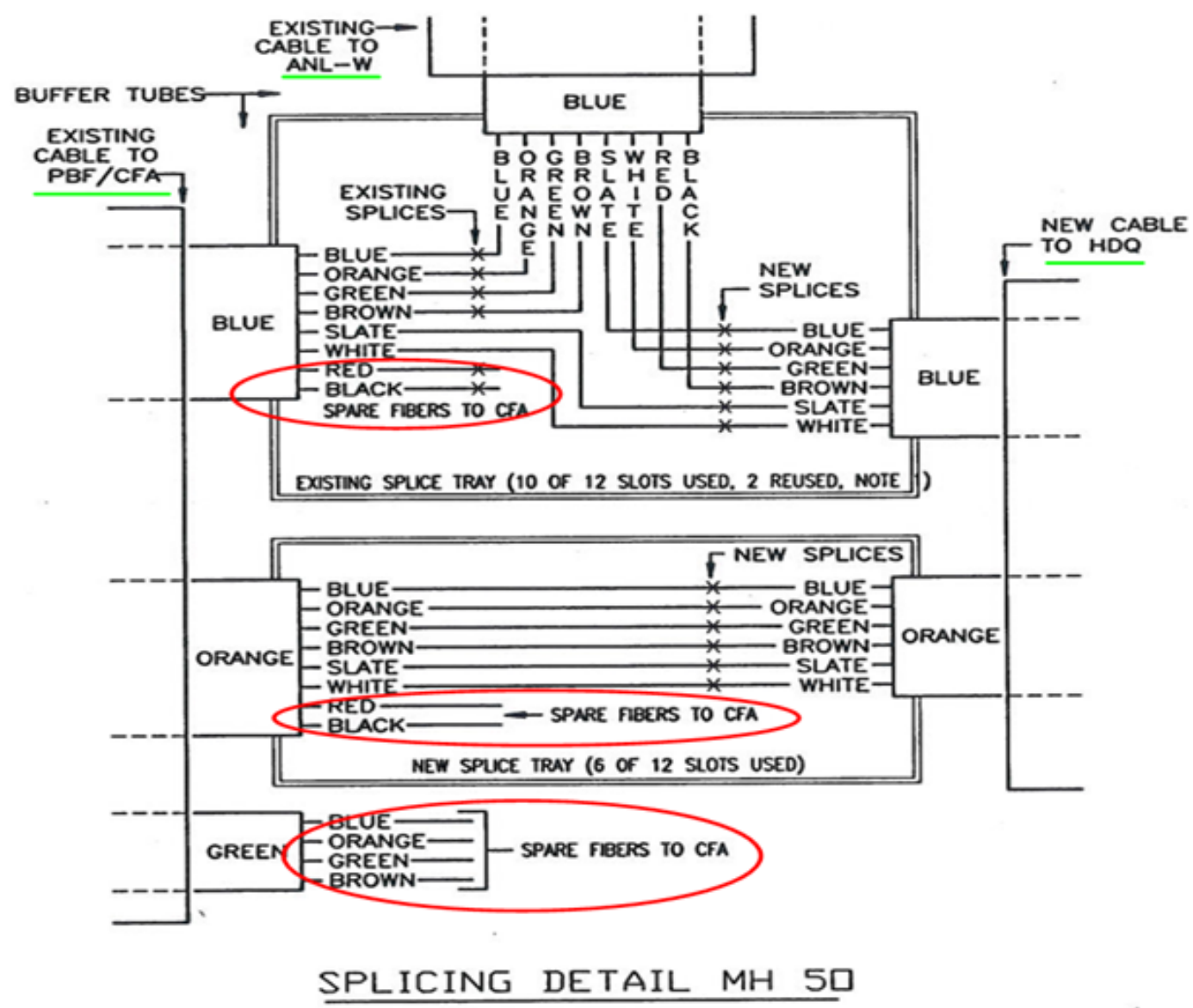




\section{RECOMMENDATION NO. 2}

Installs new duct bank from the IMCL/CESB duct bank to the new dial room and to MH8 to provide additional pathways for security requirements.

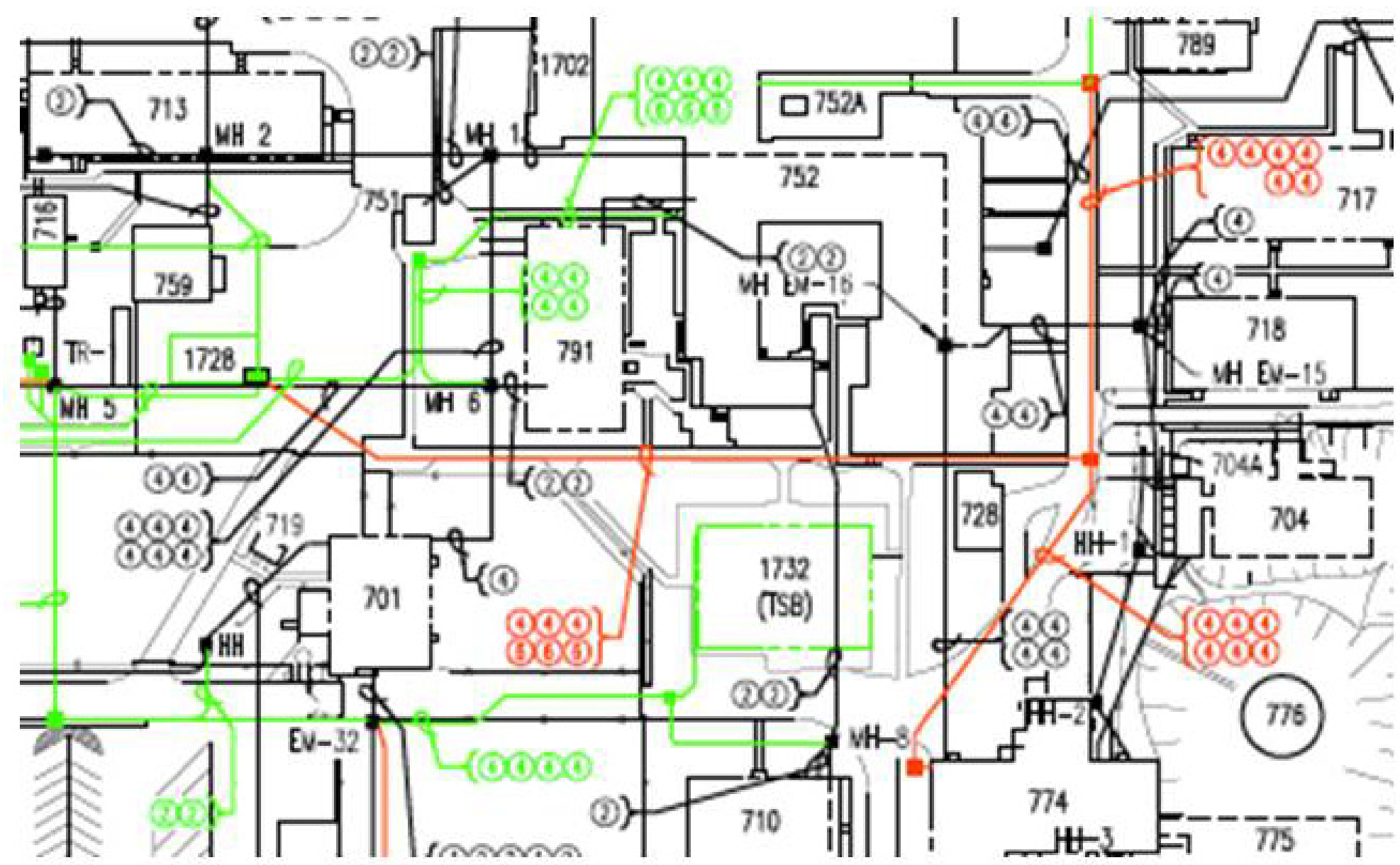




\section{ReCOMmENDATION No. 2}

Precast sidewalk with ducts will replace damaged sidewalk south of MFC-752 as an alternate duct bank route avoiding utility congestion.

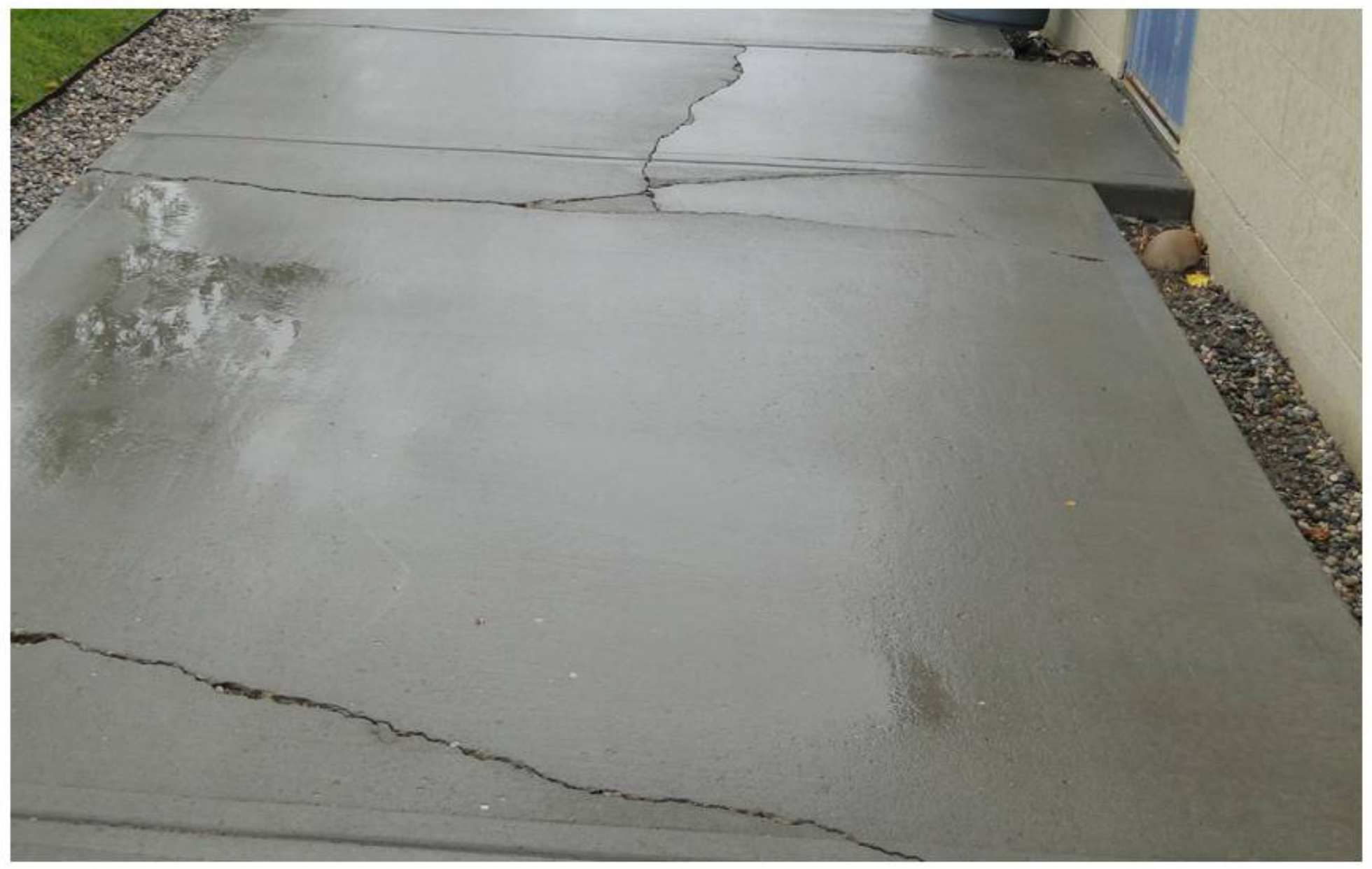




\section{RECOMMENDATION No. 3}

Install new duct bank route from MH5 to HH1. This solves a congestion problem on the sest side of the plant and also provides flexibility for future growth.

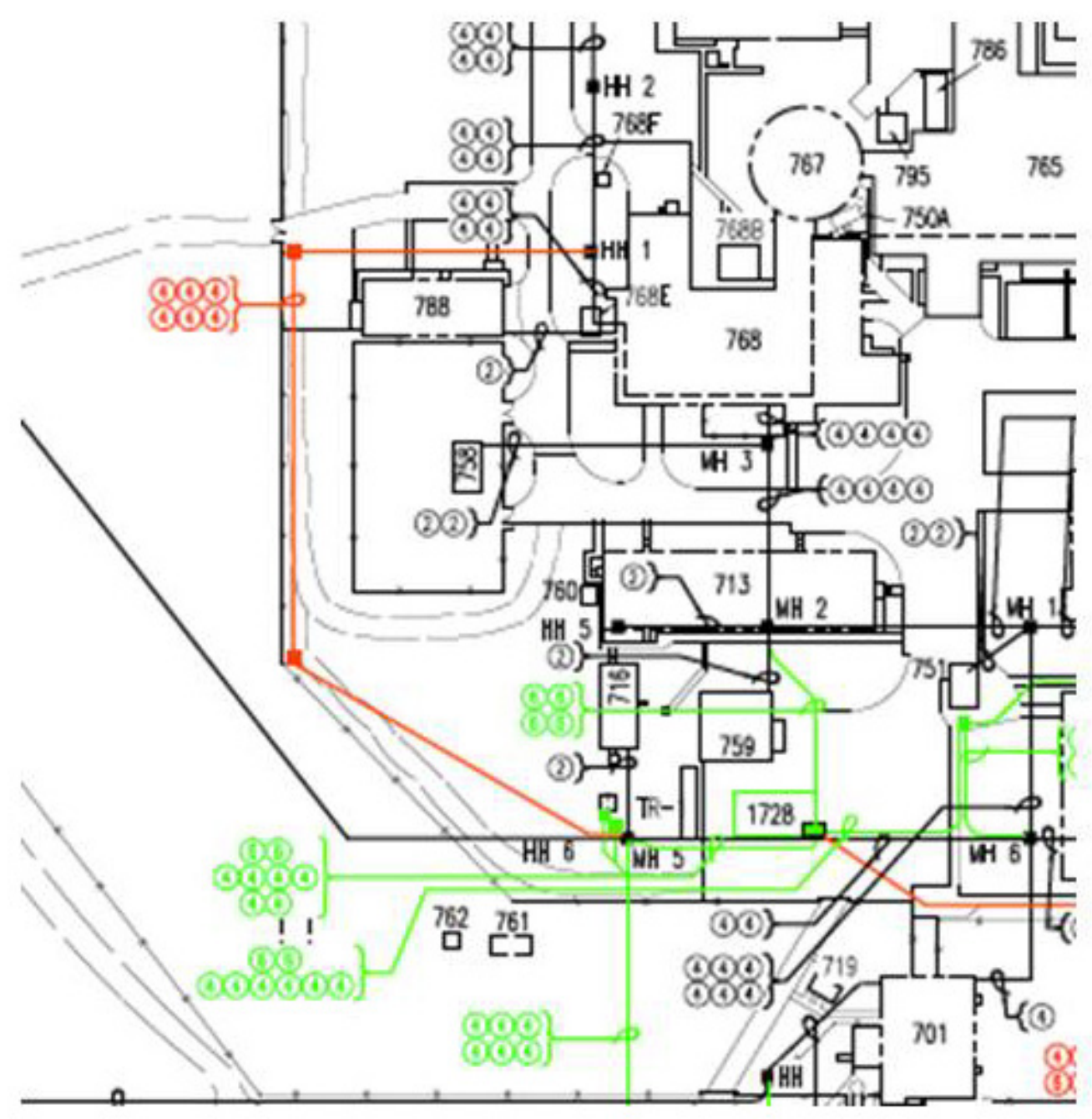


INTENTIONALLY BLANK 


\section{APPENDIX E \\ Current Projects}

The following new building projects have to been designed to meet STD-170 requirements.

\begin{tabular}{|c|c|}
\hline MFC IM Infrastructure Projects & IM Services Provided \\
\hline $\begin{array}{l}\text { MFC-1728 - Dial Room Relocation } \\
\text { New telecommunications building } \\
\text { (MFC-1728) replacing the existing } \\
\text { MFC-752 dial room }\end{array}$ & $\begin{array}{l}\text { - New ducts structures and conduits from MFC-752 } \\
\text { and other outlining manholes to the new dial room } \\
\text { - New OSP fiber and OSP copper cabling } \\
\text { - The existing dial will remain as a "cross-connect" } \\
\text { between MFC-752 and MFC-1728 to support } \\
\text { services not relocating to the new dial room. }\end{array}$ \\
\hline $\begin{array}{l}\text { MFC-1732 - Technical Support Building } \\
\text { (TSB) } \\
\text { New administrative building for } \\
\text { approximately } 80 \text { personnel }\end{array}$ & $\begin{array}{l}\text { - } \\
\text { - New duct bank, conduits } \\
\text { - } \quad \text { New Cat 6A infrastructure cabling } \\
\text { - } \quad \text { Two dedicated telecommunications rooms } \\
\text { - } \quad \text { VolP telephone service, INET, Foreign National } \\
\text { and Wireless networks. }\end{array}$ \\
\hline $\begin{array}{l}\text { MFC-1729 - Irradiated Materials } \\
\text { Characterization Laboratory (IMCL) } \\
\text { New laboratory building }\end{array}$ & $\begin{array}{l}\text { - New duct bank and conduits } \\
\text { - New OSP fiber, OSP copper, Cat } 6 \mathrm{~A} \\
\text { infrastructure cabling and a dedicated } \\
\text { telecommunications room will be provided. } \\
\text { - VolP telephone service, INET, Foreign National } \\
\text { and Wireless networks. }\end{array}$ \\
\hline $\begin{array}{l}\text { MFC-794 - Contaminated Equipment } \\
\text { Storage Building (CESB) } \\
\text { Building modification on the east side of } \\
\text { MFC-794 }\end{array}$ & $\begin{array}{l}\text { - New duct bank and conduits (in conjunction with } \\
\text { IMCL) } \\
\text { - New OSP fiber, OSP copper, Cat } 6 \mathrm{~A} \\
\text { infrastructure cabling } \\
\text { - } \quad \text { Dedicated area for telecommunications equipment } \\
\text { - INET network } \\
\text { - VoIP, Foreign National and Wireless networks not } \\
\text { required. }\end{array}$ \\
\hline
\end{tabular}

